LOCKHEED MARTIN/

ENVIRONMENTAL

RESTORATION

PROGRAM
RECEIVED

AUG 011996

OSTI

\title{
Preliminary Remediation Goals for Ecological Endpoints
}

This document has been approved by the K-25 Site Technical Information Office for release to the public. Date: $7-26-96$ 
This report has been reproduced directly from the best available copy.

Available to DOE and DOE contractors from the Office of Scientific and Technical Information, P.O. Box 62, Oak Ridge, TN 37831; prices available from 423-576-8401 (fax 423-576-2865).

Available to the public from the National Technical Information Service, U.S. Department of Commerce, 5285 Port Royal Rd., Springfield, VA 22161. 


\title{
DISCLAIMER
}

This report was prepared as an account of work sponsored by an agency of the United States Government. Neither the United States Government nor any agency thereof, nor any of their employees, makes any warranty, express or implied, or assumes any legal liability or responsibility for the accuracy, completeness, or usefulness of any information, apparatus, product, or process disclosed, or represents that its use would not infringe privately owned rights. Reference herein to any specific commercial product, process, or service by trade name, trademark, manufacturer, or otherwise does not necessarily constitute or imply its endorsement, recommendation, or favoring by the United States Government or any agency thereof. The views and opinions of authors expressed herein do not necessarily state or reflect those of the United States Government or any agency thereof.

\section{Preliminary Remediation Goals for Ecological Endpoints}

\author{
R. A. Efroymson \\ G. W. Suter II \\ B. E. Sample \\ D. S. Jones
}

Date Issued-July 1996

Prepared by the

Environmental Restoration Risk Assessment Program Lockheed Martin Energy Systems, Inc.

Oak Ridge, Tennessee 37831

Prepared for the

U.S. Department of Energy

Office of Environmental Management

under budget and reporting code EW 20

LOCKHEED MARTIN ENERGY SYSTEMS, INC. managing the

Environmental Management Activities at the

Oak Ridge K-25 Site Paducah Gaseous Diffusion Plant

Oak Ridge Y-12 Plant Portsmouth Gaseous Diffusion Plant

Oak Ridge National Laboratory

under contract DE-AC05-84OR21400

for the

U.S. DEPARTMENT OF ENERGY 



\section{. PREFACE}

This technical memorandum was prepared to present preliminary remediation goals (PRGs) for ecological endpoints for risk assessments and decision making at Comprehensive Environmental Response, Compensation, and Liability Act (CERCLA) sites. This work was performed under Work Breakdown Structure 1.4.12.2.3.04.05.02 (Activity Data Sheet 8304). Publication of this document meets an Environmental Restoration Risk Assessment Program milestone for FY 96. PRGs are upper concentration limits for specific chemicals in specific environmental media that are anticipated to protect human health or the environment. They can be used for multiple remedial investigations at multiple facilities. 
$\triangle$ 


\section{CONTENTS}

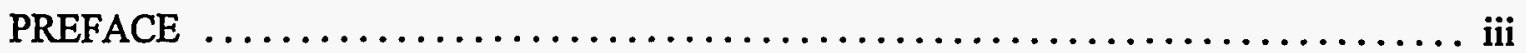

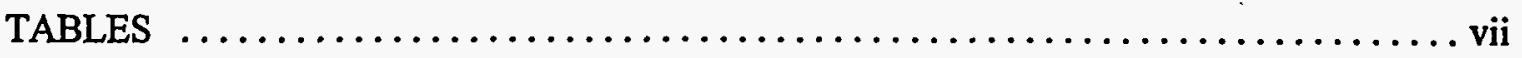

ACRONYMS $\ldots \ldots \ldots \ldots \ldots \ldots \ldots \ldots \ldots \ldots \ldots \ldots \ldots \ldots \ldots \ldots \ldots \ldots \ldots \ldots \ldots \ldots \ldots \ldots \ldots$

EXECUTIVE SUMMARY $\ldots \ldots \ldots \ldots \ldots \ldots \ldots \ldots \ldots \ldots \ldots \ldots \ldots \ldots \ldots \ldots \ldots \ldots \ldots \ldots$

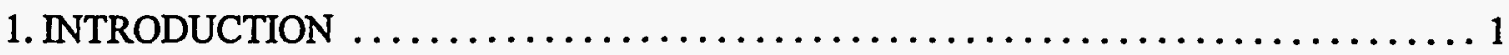

1.1 TOXICOLOGICAL BENCHMARKS AND ARARS $\ldots \ldots \ldots \ldots \ldots \ldots \ldots \ldots \ldots$

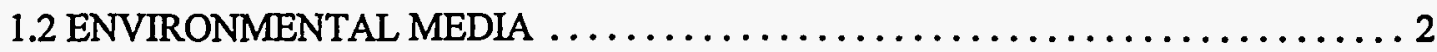

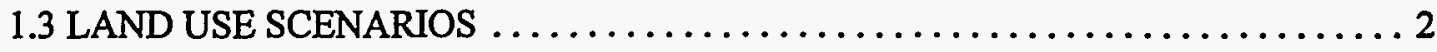

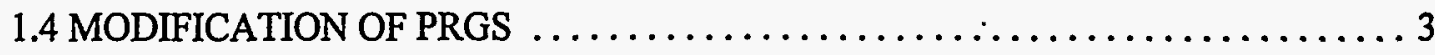

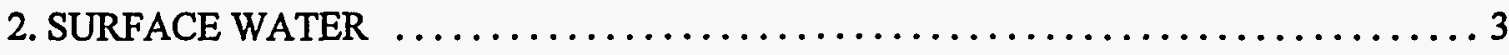

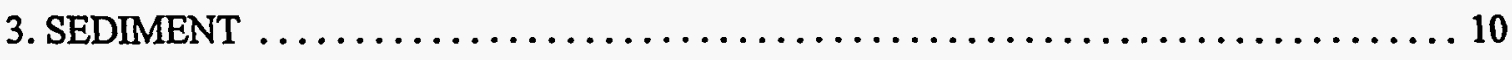

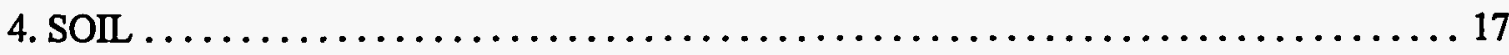

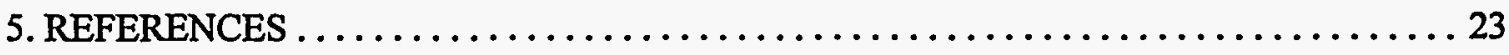




\section{TABLES}

1. Preliminary remediation goals for surface waters $\ldots \ldots \ldots \ldots \ldots \ldots \ldots \ldots \ldots \ldots$

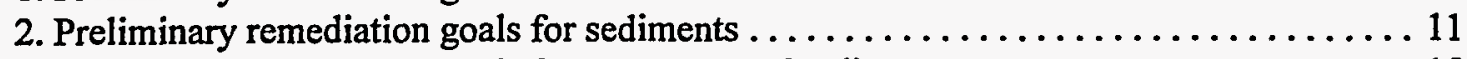

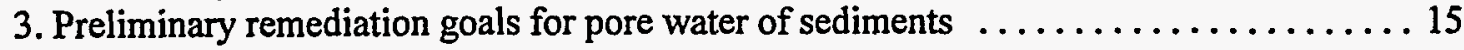

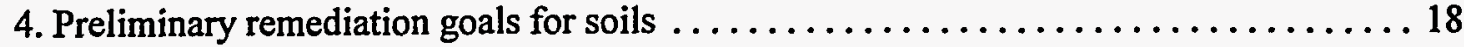

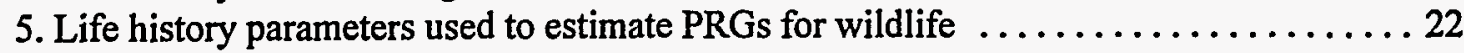

6. Summary of species-specific and final soil PRGs for wildlife $\ldots \ldots \ldots \ldots \ldots \ldots 22$

A.1. Soil PRG for red fox assumed to consume $81 \%$ small mammals, $10 \%$ plants

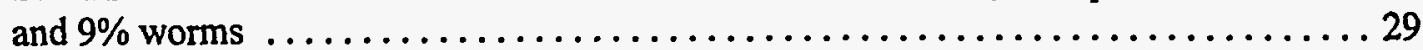

A.2. Soil PRG for white-tailed deer assumed to consume $100 \%$ plants . . . . . . . . 30

A.3. Soil PRG for white-footed mice assumed to consume $50 \%$ plants and $50 \%$ worms .... 31

A.4. Soil PRG for Short-tailed Shrews assumed to consume $100 \%$ worms $\ldots \ldots \ldots \ldots . \ldots 32$

A.5. Soil PRG for American Woodcock assumed to consume $100 \%$ worms . . . . . . . . 33

A.6. Soil PRG for red-tailed hawk assumed to consume $100 \%$ small mammals ........ 34 
L......... 


\section{ACRONYMS}

ARARs

DQOs

EPA

FACR

FAV

LOAEL

NAWQC

NOAEL

ORNL

PELS

PRGS

RBRAO

RGOs

$\mathrm{RI} / \mathrm{FS}$

SQAGs

TELs
Applicable or Relevant and Appropriate Requirements

data quality objectives

United States Environmental Protection Agency

final acute-chronic ratios

final acute values

lowest-observed-adverse-effects level

National Ambient Water Quality Criteria

no-observed- adverse-effects level

Oak Ridge National Laboratory

Probable Effects Levels

Preliminary Remediation Goals

risk-based remedial action objective

Remedial Goal Options

remedial investigation/feasibility study

Sediment Quality Assessment Guidelines

Threshold Effects Levels 


\section{EXECUTIVE SUMMARY}

Preliminary remediation goals (PRGs) are useful for risk assessment and decision making at Comprehensive Environmental Response, Compensation, and Liability Act (CERCLA) sites. PRGs are upper concentration limits for specific chemicals in specific environmental media that are anticipated to protect human health or the environment. They can be used for multiple remedial investigations at multiple facilities. In addition to media and chemicals of potential concern, the development of PRGs generally requires some knowledge or anticipation of future land use.

In Preliminary Remediation Goals for Use at the U. S. Department of Energy Oak Ridge Operations Office (Energy Systems 1995), PRGs intended to protect human health were developed with guidance from Risk Assessment Guidance for Superfund: Volume I-Human Health Evaluation Manual, Part B (RAGS) (EPA 1991). However, no guidance was given for PRGs based on ecological risk. The numbers that appear in this volume have, for the most part, been extracted from toxicological benchmarks documents for Oak Ridge National Laboratory (ORNL) and have previously been developed by ORNL. The sources of the quantities, and many of the uncertainties associated with their derivation, are described in this technical memorandum. 


\section{INTRODUCTION}

Preliminary remediation goals (PRGs) are useful for risk assessment and decision making at Comprehensive Environmental Response, Compensation, and Liability Act (CERCLA) sites. PRGs are upper concentration limits for specific chemicals in specific environmental media that are anticipated to protect human health or the environment. They can be used for multiple remedial investigations at multiple facilities. In addition to media and chemicals of potential concern, the development of PRGs generally requires some knowledge or anticipation of future land use. The development of PRGs at Oak Ridge National Laboratory (ORNL) is proceeding as two separate exercises among experts in environmental and human health sciences, but the goals are brought together during remedial investigations.

In Preliminary Remediation Goals for Use at the U. S. Department of Energy Oak Ridge Operations Office, PRGs intended to protect human health were developed with guidance from Risk Assessment Guidance for Superfund: Volume I-Human Health Evaluation Manual, Part B (RAGS). However, no guidance was given for PRGs based on ecological risk. The numbers that appear in this volume have, for the most part, been extracted from toxicological benchmarks documents for ORNL. The sources of the quantities, and many of the uncertainties associated with their derivation, are described in this technical memorandum.

PRGs are intended to correspond to minimal and acceptable levels of effects on the general ecological assessment endpoints as defined in the data quality objectives (DQO) process for ecological risk assessments on the Oak Ridge Reservation (Suter et al. 1994). In general, they correspond to small effects on individual organisms which would be expected to cause minimal effects on populations and communities. The PRGs may not be sufficiently protective of species of special concern which are based on effects on individual organisms (Suter et al. 1994). Remedial goals for such species should be developed ad hoc and should be based on no-observedadverse-effects levels (NOAELs).

\subsection{TOXICOLOGICAL BENCHMARKS AND ARARS}

Toxicological benchmarks have previously been developed at ORNL for the initial screening of contaminants for potential consideration in risk assessments. Some of these are Applicable or Relevant and Appropriate Requirements (ARARs) for remedial action, and others are quantities derived from toxicity test endpoints. Although selected benchmarks are used as PRGs in various media, the two quantities should not be confused. The major differences are:

1. Benchmarks are specific to a receptor or endpoint that is to be protected. PRGs are medium-specific.

2. PRGs are single values for each combination of chemical and medium; benchmarks differ with the assessment endpoint.

3. Benchmarks are conservative, since they are designed to exclude or to screen out only those contaminants for which there is no potential ecological concern. PRGs are regulatory values or thresholds for significant effects. 
The guidance document for human health PRGs (Energy Systems 1995) requires that remedial goals be based on ARARs or concentrations determined by risk assessment (EPA 1991). For ecological endpoints, the only federal or state ARARs are National Ambient Water Quality Criteria (NAWQC), available for more than a dozen contaminants in surface waters, and sediment quality criteria available for only five organic contaminants. The United States Environmental Protection Agency (EPA) guidance document provides no equations to protect ecological endpoints or suggested levels of protection analogous to the $10^{-6}$ risk for human carcinogens (EPA 1991).

\subsection{ENVIRONMENTAL MEDIA}

Three environmental media are considered here: surface water, sediment (including pore water), and soil. Groundwater contamination has always been assumed to have greater consequences for human health than for nonhuman organisms. Data on microscopic and other small biota of groundwater are scarce. Therefore, ecologically-based groundwater PRGs are not presented in this technical memorandum. Although contaminants of potential concern at a site can be identified based on concentrations in food for wildlife or in the organism's tissues, ultimately one of the three media mentioned previously will be remediated. Therefore, the media examined do not include "foods" and are limited to surface water, sediments, and soil.

\subsection{LAND USE SCENARIOS}

A major difference between this document and the guidance provided in RAGS and used in the human health PRGs guidance report (Energy Systems 1995) is that this report lacks emphasis on land use scenarios. For human health, land use determines human activities which determine exposure. Exposure pathways for humans can change, for example, depending on whether the land is industrial or not. Bathing may occur in residential areas and not in industrial areas; ingestion of plants (by humans) may not occur in industrial areas; and inhalation of particulates should not be significant in residential areas. Therefore, because humans engage in different activities in different locations, exposure will depend on land use.

Plants and animals, however, tend to inhabit a particular location and engage in all activities on that particular site. If a site is current or future habitat, then the PRG applies. The streams that flow through agricultural, residential, or industrial lands have the potential to support invertebrates and fish, regardless of land use. Land use types will only indirectly influence aquatic life, for example, through nutrient inputs to a stream. Similarly, exposure pathways for wildlife are not expected to change, depending on land use, though the relative emphasis of one pathway over another may be somewhat altered. If a site contains no habitat, such as a parking lot, it should be screened out during the conceptual development phase for an operable unit (i.e., before a remedial investigation is undertaken).

For lower organisms that are immersed in a medium, the spatial scale is so small that issues of land use do not usually arise (an exception may be soil organisms, as discussed in the following text). The physical habitat for organisms in a stream need not be substantially changed when land uses change. In these cases, correlations between concentrations and effects are used more often than detailed exposure equations. It is notable that ARARs (NAWQC and sediment quality criteria) are not attached to any particular land use scenario. The emphasis for ecological PRG development is on summary statistics for a wide range of effects on a wide range of organisms in a wide range of laboratory and field environments. 
Among organisms that are exposed to aquatic contaminants, land use is probably most important to piscivorous wildlife, such as osprey or mink. For some contaminants in water, PRGs are based on aquatic-feeding species. PRGs for water account for both bioaccumulation through the food chain and drinking water. Piscivores may not feed as frequently under industrial land use scenarios. However, this document recommends the same PRGs for water in all contexts because of the paucity of information on piscivore behavior.

A second exceptional case where land use may be important is during the development of PRGs for soils. Soil microbial, invertebrate, and plant communities will be dependent on the management and nutrient additions and extractions from soil. Therefore, PRGs presented for soil may be modified according to land use.

\subsection{MODIFICATION OF PRGS}

Non-ARARs-based PRGs may be modified during the remedial investigation/feasibility study (RI/FS) using site-specific data (EPA 1991). Such data may include:

1. land use assumptions;

2. exposure assumptions and habitat considerations (e.g., fraction of land that is suitable habitat);

3. environmental assumptions used for ORNL toxicological benchmarks (e.g., water hardness, soil $\mathrm{pH}$, and organic content);

4. synergistic, antagonistic, or additive effects of pollutants;

5. impacts of contamination of one medium on another (EPA 1991);

6. impacts of remediation of one medium (such as sediments) on contamination of another medium (such as surface water);

7. effects of remediation on organisms and their habitat;

8. new contaminants of concern;

9. desirable level of protection.

In addition, Remedial Goal Options (RGOs), the clean-up goals recommended in the RI/FS, can contain objectives other than concentration limits in environmental media. Two examples are to (1) prevent a contaminated plume from intersecting a stream and (2) prevent toxicity in a standard toxicity test of the contaminated medium.

\section{SURFACE WATER}

PRGs for surface waters were chosen by comparing the ORNL benchmarks for screening toxicity of contaminants to aquatic life (chronic NAWQC or secondary chronic values; Suter and 
Tsao 1996) with those for toxicity to piscivorous wildlife (LOAEL; Sample et al. 1996). The lower of the two benchmarks is the PRG listed in Table 1. If the benchmarks and therefore the PRGs are not exceeded, the contaminant concentration in water probably presents no significant ecological hazard.

Table 1. Preliminary remediation goals for surface waters

\begin{tabular}{|c|c|c|c|}
\hline Chemical & $\begin{array}{c}\text { Water } \\
\text { Concentration } \\
(\mathrm{mg} / \mathrm{L})\end{array}$ & Endpoint & Criterion \\
\hline \multicolumn{4}{|l|}{ Inorganic chemical } \\
\hline Aluminum & 0.087 & aquatic life & chronic NAWQC \\
\hline Antimony & 0.03 & aquatic life & secondary chronic value \\
\hline Arsenic III & 0.19 & piscivores & chronic NAWQC \\
\hline Arsenic V & 0.0031 & aquatic life ${ }^{2}$ & secondary chronic value \\
\hline Barium & 0.004 & aquatic life $^{2}$ & secondary chronic value \\
\hline Beryllium & 0.00066 & aquatic life $^{2}$ & secondary chronic value \\
\hline Boron & 0.0016 & aquatic life & secondary chronic value \\
\hline Cadmium & $0.0011^{1}$ & aquatic life & chronic NAWQC \\
\hline Chromium III & $0.21^{1}$ & aquatic life & chronic NAWQC \\
\hline Chromium VI & 0.011 & aquatic life & chronic NAWQC \\
\hline Cobalt & 0.023 & aquatic life ${ }^{2}$ & secondary chronic value \\
\hline Copper & $0.012^{1}$ & aquatic life & chronic NAWQC \\
\hline Cyanide & 0.0052 & aquatic life $^{2}$ & chronic NAWQC \\
\hline Iron & 1.0 & aquatic life ${ }^{2}$ & chronic NAWQC \\
\hline Lead & $0.0032^{1}$ & aquatic life & chronic NAWQC \\
\hline Lithium & 0.014 & aquatic life & secondary chronic value \\
\hline Manganese & 0.12 & aquatic life & secondary chronic value \\
\hline Mercury, inorg. or total & 0.0013 & aquatic life & secondary chronic value \\
\hline Mercury, methyl & 0.0000026 & piscivores & from river otter $L O A E L$ \\
\hline
\end{tabular}


Table 1. (continued)

\begin{tabular}{|c|c|c|c|}
\hline Chemical & $\begin{array}{c}\text { Water } \\
\text { Concentration } \\
(\mathrm{mg} / \mathrm{L})\end{array}$ & Endpoint & Criterion \\
\hline Molybdenum & 0.37 & aquatic life & secondary chronic value \\
\hline Nickel & $0.16^{1}$ & aquatic life & chronic NAWQC \\
\hline Selenium & 0.00039 & piscivores & from river otter LOAEL \\
\hline Silver & 0.00036 & aquatic life & secondary chronic value \\
\hline Strontium & 1.5 & aquatic life ${ }^{2}$ & secondary chronic value \\
\hline Thallium & 0.009 & piscivores & from river otter LOAEL \\
\hline Tin & 0.073 & aquatic life & secondary chronic value \\
\hline Uranium & 0.0026 & aquatic life ${ }^{2}$ & secondary chronic value \\
\hline Vanadium & 0.020 & aquatic life & secondary chronic value \\
\hline Zinc & $0.11^{1}$ & aquatic life & chronic NAWQC \\
\hline Zirconium & 0.017 & aquatic life ${ }^{2}$ & secondary chronic value \\
\hline \multicolumn{4}{|l|}{ Organic Chemical } \\
\hline Acenaphthene & 0.023 & aquatic life ${ }^{2}$ & chronic NAWQC \\
\hline Acetone & 1.5 & aquatic life & secondary chronic value \\
\hline Anthracene & 0.00073 & aquatic life ${ }^{2}$ & secondary chronic value \\
\hline Benzene & 0.13 & aquatic life & secondary chronic value \\
\hline Benzidene & 0.0039 & aquatic life ${ }^{2}$ & secondary chronic value \\
\hline Benzo(a)anthracene & 0.000027 & aquatic life ${ }^{2}$ & secondary chronic value \\
\hline Benzo(a)pyrene & 0.000014 & aquatic life & secondary chronic value \\
\hline Benzoic acid & 0.042 & aquatic life ${ }^{2}$ & secondary chronic value \\
\hline Benzyl alcohol & 0.0086 & aquatic life ${ }^{2}$ & secondary chronic value \\
\hline BHC, gamma (lindane) & 0.00008 & aquatic life ${ }^{2}$ & chronic NAWQC \\
\hline BHC (other) & 0.0000040 & piscivores & from river otter LOAEL \\
\hline
\end{tabular}


Table 1. (continued)

\begin{tabular}{|c|c|c|c|}
\hline Chemical & $\begin{array}{c}\text { Water } \\
\text { Concentration } \\
(\mathrm{mg} / \mathrm{L})\end{array}$ & Endpoint & Criterion \\
\hline Biphenyl & 0.014 & aquatic life ${ }^{2}$ & secondary chronic value \\
\hline Bis(2-ethylhexyl) phthalate & 0.00012 & aquatic life & from river otter LOAEL \\
\hline 2-Butanone & 14 & aquatic life ${ }^{2}$ & secondary chronic value \\
\hline Butylbenzyl phthalate & 0.019 & aquatic life ${ }^{2}$ & secondary chronic value \\
\hline Carbon disulfide & 0.00092 & aquatic life ${ }^{2}$ & secondary chronic value \\
\hline Carbon tetrachloride & 0.0098 & aquatic life ${ }^{2}$ & secondary chronic value \\
\hline Chlordane & 0.000037 & piscivores & from river otter LOAEL \\
\hline Chlorobenzene & 0.064 & aquatic life ${ }^{2}$ & secondary chronic value \\
\hline Chloroform & 0.028 & aquatic life & secondary chronic value \\
\hline DDD p,p' & $4.1 \times 10^{-83}$ & piscivores & $\begin{array}{l}\text { from belted kingfisher } \\
\text { LOAEL }\end{array}$ \\
\hline DDT & $4.1 \times 10^{-83}$ & piscivores & $\begin{array}{l}\text { from belted kingfisher } \\
\text { LOAEL }\end{array}$ \\
\hline Decane & 0.049 & aquatic life ${ }^{2}$ & secondary chronic value \\
\hline Diazinon & 0.000043 & aquatic life ${ }^{2}$ & secondary chronic value \\
\hline Dibenzofuran & 0.0037 & aquatic life ${ }^{2}$ & secondary chronic value \\
\hline 1,2-Dichlorobenzene & 0.014 & aquatic life ${ }^{2}$ & secondary chronic value \\
\hline 1,3-Dichlorobenzene & 0.071 & aquatic life $e^{2}$ & secondary chronic value \\
\hline 1,4-Dichlorobenzene & 0.015 & aquatic life ${ }^{2}$ & secondary chronic value \\
\hline 1,1-Dichloroethane & 0.047 & aquatic life ${ }^{2}$ & secondary chronic value \\
\hline 1,2-Dichloroethane & 0.91 & aquatic life & secondary chronic value \\
\hline 1,1-Dichloroethene & 0.025 & aquatic life ${ }^{2}$ & secondary chronic value \\
\hline 1,2-Dichloroethenes & 0.59 & aquatic life ${ }^{2}$ & secondary chronic value \\
\hline 1,1-Dichloropropene & 0.000055 & aquatic life ${ }^{2}$ & secondary chronic value \\
\hline Di-n-butyl phthalate & 0.001 & piscivores & $\begin{array}{l}\text { from belted kingfisher } \\
\text { LOAEL }\end{array}$ \\
\hline
\end{tabular}


Table 1. (continued)

\begin{tabular}{|c|c|c|c|}
\hline Chemical & $\begin{array}{c}\text { Water } \\
\text { Concentration } \\
(\mathrm{mg} / \mathrm{L})\end{array}$ & Endpoint & Criterion \\
\hline Diethyl phthalate & 0.21 & aquatic life $^{2}$ & secondary chronic value \\
\hline Endosulfan & 0.000051 & aquatic life ${ }^{2}$ & secondary chronic value \\
\hline Endrin & 0.000061 & aquatic life ${ }^{2}$ & chronic NAWQC \\
\hline Ethyl benzene & 0.0073 & aquatic life $^{2}$ & secondary chronic value \\
\hline Fluoranthene & 0.0062 & aquatic life ${ }^{2}$ & chronic NAWQC \\
\hline Fluorene & 0.0039 & aquatic life ${ }^{2}$ & secondary chronic value \\
\hline Heptachlor & 0.0000069 & aquatic life & secondary chronic value \\
\hline Hexachloroethane & 0.012 & aquatic life ${ }^{2}$ & secondary chronic value \\
\hline Hexane & 0.00058 & aquatic life ${ }^{2}$ & secondary chronic value \\
\hline 2-Hexanone & 0.099 & aquatic life $^{2}$ & secondary chronic value \\
\hline Methoxychlor & 0.000019 & aquatic life ${ }^{2}$ & secondary chronic value \\
\hline 1-Methylnaphthalene & 0.0021 & aquatic life ${ }^{2}$ & secondary chronic value \\
\hline 4-Methyl-2-pentanone & 0.17 & aquatic life ${ }^{2}$ & secondary chronic value \\
\hline 2-Methylphenol & 0.013 & aquatic life ${ }^{2}$ & secondary chronic value \\
\hline Methylene chloride & 2.2 & aquatic life $^{2}$ & secondary chronic value \\
\hline Naphthalene & 0.012 & aquatic life ${ }^{2}$ & secondary chronic value \\
\hline 4-Nitrophenol & 0.30 & aquatic life ${ }^{2}$ & secondary chronic value \\
\hline N-Nitrosodiphenylamine & 0.21 & aquatic life ${ }^{2}$ & secondary chronic value \\
\hline 2-Octanone & 0.0083 & aquatic life ${ }^{2}$ & secondary chronic value \\
\hline PCBs total & $0.0000019^{4}$ & piscivores & from river otter LOAEL ${ }^{4}$ \\
\hline Aroclor 1016 & $0.00023^{5}$ & piscivores & from river otter LOAEL \\
\hline Aroclor 1221 & 0.00028 & aquatic life ${ }^{2}$ & secondary chronic value \\
\hline Aroclor 1232 & 0.00058 & aquatic life ${ }^{2}$ & secondary chronic value \\
\hline
\end{tabular}


Table 1. (continued)

\begin{tabular}{|c|c|c|c|}
\hline Chemical & $\begin{array}{c}\text { Water } \\
\text { Concentration } \\
(\mathrm{mg} / \mathrm{L})\end{array}$ & Endpoint & Criterion \\
\hline Aroclor 1242 & 0.000047 & piscivores & from river otter LOAEL \\
\hline Aroclor 1248 & 0.0000019 & piscivores & from river otter LOAEL \\
\hline Aroclor 1254 & 0.0000019 & piscivores & from river otter LOAEL \\
\hline Aroclor 1260 & 0.094 & aquatic life ${ }^{2}$ & secondary chronic value \\
\hline Pentachlorobenzene & 0.00047 & aquatic life ${ }^{2}$ & secondary chronic value \\
\hline 1-Pentanol & 0.11 & aquatic life ${ }^{2}$ & secondary chronic value \\
\hline Phenanthrene & 0.0063 & aquatic life ${ }^{2}$ & secondary chronic value \\
\hline Phenol & 0.11 & aquatic life ${ }^{2}$ & secondary chronic value \\
\hline 2-Propanol & 0.0075 & aquatic life $^{2}$ & secondary chronic value \\
\hline 1,1,2,2-Tetrachloroethane & 0.61 & aquatic life ${ }^{2}$ & secondary chronic value \\
\hline Tetrachloroethene & 0.098 & aquatic life ${ }^{2}$ & secondary chronic value \\
\hline Toluene & 0.0098 & aquatic life & secondary chronic value \\
\hline Tribromomethane & 0.32 & aquatic life ${ }^{2}$ & secondary chronic value \\
\hline 1,2,4-Trichlorobenzene & 0.11 & aquatic life ${ }^{2}$ & secondary chronic value \\
\hline 1,1,1-Trichloroethane & 0.011 & aquatic life $^{2}$ & secondary chronic value \\
\hline 1,1,2-Trichloroethane & 1.2 & aquatic life ${ }^{2}$ & secondary chronic value \\
\hline Trichloroethene & 0.47 & aquatic life & secondary chronic value \\
\hline Vinyl acetate & 0.016 & aquatic life ${ }^{2}$ & secondary chronic value \\
\hline Vinyl chloride & 0.782 & piscivores 5 & from river otter LOAEL \\
\hline
\end{tabular}


Table 1. (continued)

\begin{tabular}{l} 
Chemical $\begin{array}{c}\text { Water } \\
\text { Concentration } \\
(\mathrm{mg} / \mathrm{L})\end{array}$ \\
\hline Xylene \\
Notes: \\
1 Hardness dependent criterion for aquatic life benchmark normalized to $100 \mathrm{mg} / \mathrm{L}$. \\
2 Toxic concentration benchmarks are not available for piscivorous wildlife. Therefore, the PRG cannot \\
be assumed to protect wildlife. \\
3 Only a single value was available for DDT and metabolites, though different benchmarks were available \\
for the protection of aquatic life. \\
The lowest available concentration for the protection of piscivores from any Aroclor (1248) was used. \\
Toxic concentration benchmarks are not available for aquatic life. Therefore, the PRG cannot be assumed \\
to protect fish or aquatic invertebrates.
\end{tabular}

Since the NAWQC are ARARs for remedial action, they serve as the basis for screening contaminants in water. The chronic NAWQCs are EPA's calculation of final acute values (FAV) divided by final acute-chronic ratios (FACR), where the FAV is the fifth percentile of 48- to 96-hour median lethal concentration (LC50) values or equivalent median effective concentration (EC50) values for each criterion chemical. The FACR is the geometric mean of quotients of at least three LC50/CV ratios from tests of different families of aquatic organisms (Stephan et al. 1985). For several metals, NAWQC are functions of water hardness, and the default PRGs for those metals assume a water hardness of $100 \mathrm{mg} / \mathrm{L}$. However, site-specific water hardness may be substantially different, thereby altering the magnitude or perhaps the direction of the difference between the aquatic life and piscivore toxicological benchmarks.

In this technical memorandum, as well as in the report by Suter and Tsao (1996), NAWQC are not included as potential PRGs for aquatic life if they are based on the protection of humans or other piscivores. This is because ecological PRGs should not be based on effects on humans, and the PRGs based on protection of aquatic life may be lower than the NAWQCs based on fish consumption. In addition, they are not used as potential PRGs for piscivorous wildlife because they are not as rigorously derived or as appropriate to wildlife as the values derived by Opresko et al. (1995).

Where NAWQC were not available, secondary chronic values were derived to be used as benchmarks for screening contaminants for toxicity to aquatic life (Suter and Tsao 1996). These values rely on fewer data than do the NAWQC. The method for calculating the secondary chronic value is described in EPA's Proposed Water Quality Guidance for the Great Lakes System (1993) and is explained by Suter and Tsao (1996).

For chemicals that are bioaccumulated by piscivores, benchmarks that protect these wildlife may be lower aqueous concentrations than those that protect the aquatic life within the stream. The benchmarks used for wildlife species that feed primarily on aquatic organisms were derived by Sample et al. (1996). The mammalian and avian species considered in the document are representative of wildlife found on the Oak Ridge Reservation. To obtain PRGs, lowestobserved-adverse-effects levels (LOAELS) rather than NOAELs are compared to surface water toxicological benchmarks because (1) NOAELs alone give no indication as to how much higher a concentration must be before adverse effects are observed (LOAELs are presumed to be the threshold levels at which effects become evident), (2) NOAELs often have more uncertainties associated with them than do LOAELs (see Opresko et al. 1995), and (3) LOAELs for effects on 
individual wildlife are expected to correspond to no-effect or negligible-effect levels on wildlife populations. The equation used for calculating the LOAEL-based wildlife benchmarks is:

$$
\mathrm{C}_{\mathrm{w}}=\left(\mathrm{LOAEL}_{\mathrm{w}} \times \mathrm{bw}_{\mathrm{w}}\right) /[\mathrm{W}+(\mathrm{F} \times \mathrm{BAF})] \quad \text { (Opresko et al. 1995), }
$$

which is equivalent to those used by the EPA (1993) where:

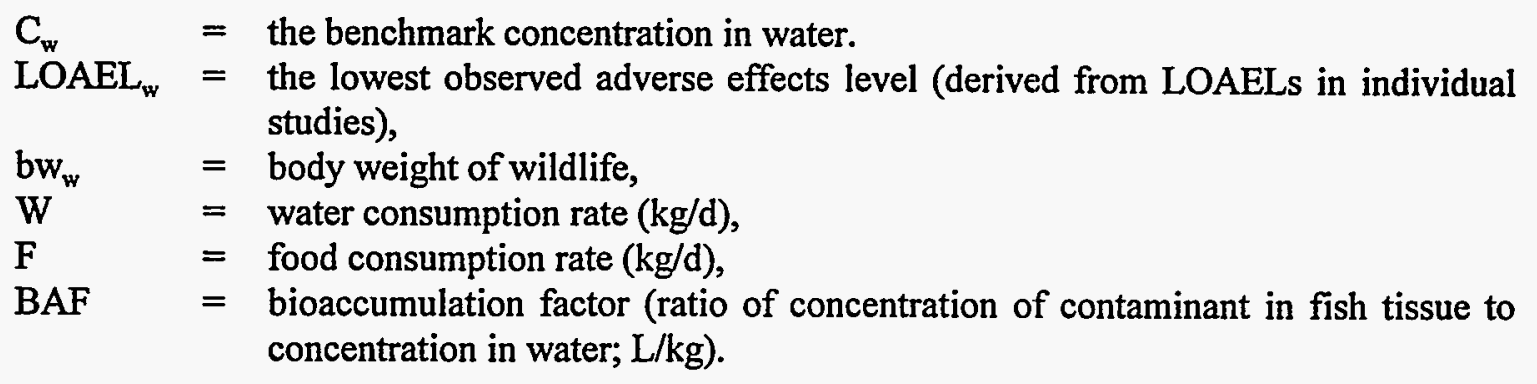

For most of the analytes listed in Table 1, the chronic NAWQC or the secondary chronic value is the PRG. For several analytes, the PRG is based on the LOAEL for mink. However, one analyte, di-n-butyl phthalate, has a PRG that is derived from an avian LOAEL. For some analytes listed in Table 1, piscivore benchmarks were not available. Therefore, in these cases, the concentration cannot be assumed to protect piscivores, and the PRGs may change as the data gaps are filled.

\section{SEDIMENT}

Organisms that reside in sediments are exposed to different concentrations of contaminants from those in the water column. Chemicals in sediment may be present at higher concentrations and for longer time periods than chemicals dissolved in the surface water. Both the concentrations of chemicals in the solid phase of sediments and concentrations in the pore water are relevant to the exposure of benthic (sediment) organisms, and PRGs are presented for both media (Tables 2 and 3). If PRGs are available for both sediment and pore water, the PRG that is determined by the remedial investigation to be the best estimate of risk to sediment biota should take precedence. It is assumed that benthic organisms, including fish, are not significant constituents of the diets of mammalian and avian piscivores; therefore, piscivores are not determinants of PRGs for sediment, as they sometimes are for surface waters. If sediments are to be dredged and disposed of on land, PRGs for soil, as well as PRGs for sediments, should be considered. PRGs for sediments are taken from one of seven sources.

The lowest value of the following sediment toxicity benchmarks for each chemical is the PRG: (1) sediment quality criteria proposed by EPA (EPA 1993b-f); (2) sediment criteria based on the chronic NAWQC; (3) criteria calculated from the lowest chronic value for fish, daphnids, or other invertebrates in surface waters; 4) the NOAA Effects Range-Meclian (ER-M); or (5) the Florida Department of Environmental Protection Probable Effect Level (PEL). All of these are described at length by Jones et al. (1996), and the lowest chronic values are not used as the PRG if they were originally estimated from acute toxicity (Suter and Tsao 1996). If these criteria are not available, the PRG is the lower of (1) the sediment benchmark calculated from the secondary chronic value for aquatic toxicity or (2) the Ontario Ministry of the Environment Severe Effect Level. The secondary chronic value is often one or two orders of magnitude lower than the lowest chronic values; therefore, PRGs based on this value are likely to be more conservative than other PRGs. 
The five sediment quality criteria proposed in 1993 by EPA (EPA 1993b-f) are potential ARARs for assessing sediment quality with respect to acenaphthene, dieldrin, endrin, fluoranthene, and phenanthrene at hazardous waste sites. These and the ER-Ms and PELs were the only potential PRGs for organic chemicals that were not calculated based on partitioning between water and sediment.

Table 2. Preliminary remediation goals for sediments

\begin{tabular}{|c|c|c|}
\hline Chemical & $\begin{array}{c}\text { Sediment Concentration } \\
(\mathrm{mg} / \mathrm{kg})\end{array}$ & Type of Benchmark' \\
\hline \multicolumn{3}{|l|}{ Organic chemical } \\
\hline Acenaphthene & 0.089 & PEL \\
\hline Acenaphthylene & 0.13 & PEL \\
\hline Acetone $^{2}$ & 0.0091 & LCV for daphnid \\
\hline Aldrin & 0.080 & Ontario Ministry of the Environment-severe \\
\hline Anthracene & 0.25 & PEL \\
\hline Benzene & 0.16 & SCV \\
\hline Benzidine $^{2}$ & 0.0017 & SCV \\
\hline Benzo(a)anthracene & 0.69 & PEL \\
\hline Benzo(a)pyrene & 0.76 & PEL \\
\hline Benzyl alcohol ${ }^{2}$ & 0.0011 & SCV \\
\hline Biphenyl & 1.1 & SCV \\
\hline Bis(2-ethylhexyl)phthalate & 2.7 & PEL \\
\hline 4-Bromophenyl phenyl ether & 1.2 & SCV \\
\hline 2-Butanone ${ }^{2}$ & 0.27 & SCV \\
\hline Carbon disulfide & 0.00086 & SCV \\
\hline Carbon tetrachloride & 2.0 & LCV for fish \\
\hline Chlordane & 0.0048 & PEL \\
\hline Chlorobenzene & 0.417 & SCV \\
\hline Chloroform & 0.96 & LCV for fish \\
\hline
\end{tabular}


12

Table 2. (continued)

\begin{tabular}{|c|c|c|}
\hline Chemical & $\begin{array}{l}\text { Sediment Concentration } \\
(\mathrm{mg} / \mathrm{kg})\end{array}$ & Type of Benchmark ${ }^{1}$ \\
\hline Chrysene & 0.85 & $\overline{\text { PEL }}$ \\
\hline Decane & 41 & SCV \\
\hline DDD p,p' & 0.0078 & PEL \\
\hline $\mathrm{DDE} p, \mathrm{p}^{\prime}$ & 0.027 & ER-M \\
\hline DDT & 0.052 & PEL \\
\hline Diazinon & 0.0019 & SCV \\
\hline Dibenzo(a,h)anthracene & 0.14 & PEL \\
\hline Dibenzofuran & 0.42 & SCV \\
\hline 1,2-Dichlorobenzene & 0.33 & SCV \\
\hline 1,3-Dichlorobenzene & 1.7 & SCV \\
\hline 1,4-Dichlorobenzene & 0.35 & SCV \\
\hline 1,1-Dichloroethane & 0.027 & SCV \\
\hline 1,2-Dichloroethane & 4.3 & LCV for daphnid \\
\hline 1,1-Dichloroethylene & 3.5 & LCV for fish \\
\hline 1,2-Dichloroethylene & 0.40 & SCV \\
\hline 1,3-Dichloropropene & 0.23 & LCV for fish \\
\hline Di-n-butyl phthalate & 240 & LCV for daphnid \\
\hline Diethyl phthalate & 0.61 & SCV \\
\hline Dieldrin & 0.0043 & PEL \\
\hline Endosulfan & 0.0055 & SCV \\
\hline Endrin & 0.045 & ER-M \\
\hline Ethyl benzene & 5.4 & LCV for fish \\
\hline Fluoranthene & 1.5 & PEL \\
\hline Fluorene & 0.14 & PEL \\
\hline
\end{tabular}


13

Table 2. (continued)

\begin{tabular}{|c|c|c|}
\hline Chemical & $\begin{array}{l}\text { Sediment Concentration } \\
(\mathrm{mg} / \mathrm{kg})\end{array}$ & Type of Benchmark ${ }^{1}$ \\
\hline Heptachlor & 13 & LCV for fish \\
\hline Hexachloroethane & 1.0 & SCV \\
\hline Hexane & 0.040 & SCV \\
\hline 2-Hexanone ${ }^{2}$ & 0.023 & SCV \\
\hline Lindane (gamma BHC) & 0.00099 & PEL \\
\hline Methoxychlor & 0.019 & SCV \\
\hline Methylene chloride & 18 & LCV for fish \\
\hline 4-Methyl-2-pentanone ${ }^{2}$ & 15 & LCV for fish \\
\hline 2-Methylphenol ${ }^{2}$ & 0.012 & SCV \\
\hline Naphthalene & 0.39 & PEL \\
\hline 2-Octanone ${ }^{2}$ & 0.018 & SCV \\
\hline PCBs total & 0.18 & PEL \\
\hline Aroclor 1221 & 0.12 & SCV \\
\hline Aroclor 1232 & 0.60 & SCV \\
\hline Aroclor 1242 & 29 & LCV for fish \\
\hline Aroclor 1248 & 1.0 & SCV \\
\hline Aroclor 1254 & 72 & LCV for fish \\
\hline Aroclor 1260 & 63 & LCV for fish \\
\hline Pentachlorobenzene & 0.70 & SCV \\
\hline 1-Pentanol ${ }^{2}$ & 0.034 & SCV \\
\hline Phenanthrene & 0.54 & PEL \\
\hline Phenol & 0.032 & chronic NAWQC \\
\hline 2-Propanol ${ }^{2}$ & 0.000084 & SCV \\
\hline
\end{tabular}


Table 2. (continued)

$\begin{array}{ccc}\text { Chemical } & \begin{array}{c}\text { Sediment Concentration } \\ (\mathrm{mg} / \mathrm{kg})\end{array} & \text { Type of Benchmark }\end{array}$

Pyrene

1,1,2,2-Tetrachloroethane

Tetrachloroethylene

Toluene

Tribromomethane

1,2,4-Trichlorobenzene

1,1,1-Trichloroethane

1,1,2-Trichloroethane

Trichloroethene

Vinyl acetate

Xylene

Inorganic chemical

Arsenic

Cadmium

Chromium

Copper

Lead

Mercury

Nickel

Silver

Zinc
1.4

5.4

0.66

9.7

52

0.00084

0.16

42

160

110

110

0.7

43

1.8

270
PEL

LCV for fish

LCV for daphnid

SCV

SCV

SCV

LCV for fish

LCV for fish

LCV for fish

SCV

SCV

PEL

PEL

PEL

PEL

PEL

PEL

PEL

PEL

PEL

Notes:

1 PEL, Florida Department of Environmental Protection Probable Effects Level (Macdonald 1994); ER-M, NOAA Effects Range-Median (Long et al. 1995); SCV, secondary chronic value (Jones et al. 1996); LCV, lowest chronic value for daphnids, non-daphnid invertebrates, or fish; Ontario Ministry of the Environment - severe, severe effects level

2 Denotes polar nonionic organic compounds, for which the equilibrium partitioning model is likely to provide a conservative model of exposure. 
For nonionic organic chemicals for which octanol-water partition coefficients are available, sediment toxicity benchmarks were calculated based on equilibrium partitioning, assuming $1 \%$ organic carbon and using the benchmarks for surface waters (NAWQC, secondary chronic values, and lowest chronic values for fish, daphnids, and non-daphnid invertebrates). These benchmarks were considered as possible PRGs, with lower concentrations selected according to the priority discussed previously. An advantage of the equilibrium partitioning approach is that the PRG can be adapted to different sites by adjusting the organic carbon parameter. Both the sediment quality criteria and the equilibrium partitioning benchmarks have been used by ORNL to screen for contaminants of potential concern for ecological risk assessments (Jones et al. 1996). The equation originally used by EPA (1989) and then used by Jones et al. (1996) is:

$$
S Q B=f_{o c} \times K_{o c} \times W Q B \text {, }
$$

where:

$\mathrm{SQB}=$ sediment quality benchmark,

$\mathrm{f}_{\mathrm{oc}}=$ mass fraction of organic carbon,

$\mathrm{K}_{\mathrm{oc}}=$ organic carbon-water partition coefficient,

$\mathrm{WQB}=$ water quality benchmark.

The derivation of the equation is given by Jones et al. (1996). The biological assumptions of the equilibrium partitioning approach, according to Jones et al. (1996), are:

1. the sensitivities of benthic species and species tested to derive WQC, predominantly water column species, are similar;

2. the levels of protection afforded by WQC are appropriate for benthic organisms; and

3. exposures are similar regardless of feeding type or habitat (EPA 1993b).

Sediments and pore water are assumed to be in continual equilibrium (MacDonald 1994a).

Table 3. Preliminary remediation goals for pore water of sediments (to be used with Table 1$)^{2}$

\begin{tabular}{|c|c|c|}
\hline Chemical & $\begin{array}{c}\text { Water } \\
\text { Concentration } \\
(\mathrm{mg} / \mathrm{L})\end{array}$ & Criterion \\
\hline \multicolumn{3}{|l|}{ Inorganic chemical } \\
\hline Arsenic III & 0.19 & chronic NAWQC \\
\hline Mercury, methyl & 0.0000028 & secondary chronic value \\
\hline Selenium & 0.005 & chronic NAWQC \\
\hline Thallium & 0.012 & secondary chronic value \\
\hline
\end{tabular}


Table 3. (continued)

\begin{tabular}{lcl}
\hline \multicolumn{1}{c}{ Chemical } & $\begin{array}{c}\text { Water } \\
\text { Concentration } \\
(\mathrm{mg} / \mathrm{L})\end{array}$ & Criterion \\
\hline Organic chemical & 0.0022 & secondary chronic value \\
BHC (other than gamma) & 0.000011 & secondary chronic value \\
DDD p,p' & 0.000013 & secondary chronic value \\
DDT & 0.035 & secondary chronic value \\
Di-n-butyl phthalate & 0.00014 & secondary chronic value \\
PCBs total & 0.000053 & secondary chronic value \\
Aroclor 1242 & 0.000081 & secondary chronic value \\
Aroclor 1248 & 0.000033 & secondary chronic value \\
Aroclor 1254 & 0.013 & secondary chronic value \\
Xylene & &
\end{tabular}

Notes:

1 Hardness dependent criterion for aquatic life benchmark normalized to $100 \mathrm{mg} / \mathrm{L}$.

2 PRGs for pore water are presented in Table 1 except for surface water values that were based on risk in piscivores. PRGs for those chemicals are listed here and obtained from Suter and Tsao (1996).

PRGs for inorganic chemicals in sediments are taken from the Florida Sediment Quality Assessment Guidelines (SQAGs) (MacDonald 1994a). The SQAGs include Threshold Effects Levels (TELs), "the upper limit of the range of sediment contaminant concentrations dominated by no effects data entries ... [and] not considered to represent significant hazards to aquatic organisms" and Probable Effects Levels (PELs), "the lower limit of the range of contaminant concentrations that are usually or always associated with adverse biological effects" (MacDonald 1994a). In this document, PELs are used as PRGs for several metals. The calculation used is:

$$
\mathrm{PEL}=\sqrt{\mathrm{EDS}_{\mathrm{m}} \times \mathrm{NEDS}_{\mathrm{H}}}
$$

where $\mathrm{EDS}_{\mathrm{m}}$ is the 50th percentile concentration in the effects data set, and NEDS $\mathrm{H}_{\mathrm{H}}$ is the 85th percentile concentration in the no effects data set. Few data exist on chronic effects of contaminants on organisms in sediments; therefore, many of the studies present acute responses.

The Florida SQAGs were designed for prioritizing risk management actions, interpreting and designing monitoring programs for sediment contamination, designing wetland restoration programs, supporting decisions by multiple parties relating to sediments, etc. They were not intended for use as sediment quality criteria (MacDonald 1994a). The SQAGs were designed for use in marine and estuarine systems only. In addition, factors that influence bioavailability of metals at a site, such as 
acid volatile sulfide for divalent cations, are not taken into account by these guidelines or PRGs (MacDonald 1994a).

Jones et al. (1996) caution that the sediment benchmarks do not represent remedial goals, since the removal or other disturbance of sediment can affect habitat or cause toxic effects in surface water. Similarly, MacDonald (1994a) suggests that the Florida SQAGs should not be used directly as clean-up targets for hazardous sites without additional site-specific studies. The PRGs for sediments are not ideal and should be modified on a site-by-site basis. Nonetheless, they are the best and most current remedial goals available to protect nonhuman organisms and ecological systems in the absence of reliable sediment toxicity benchmarks.

Although sediments are usually identified for remediation on the basis of their bulk concentrations, in some cases pore water concentrations are the appropriate PRG because the toxicity of the sediment is more clearly associated with the pore water than bulk sediment contaminant levels. This circumstance will occur when the toxicity is primarily due to exposure to pore water, and variance in sediment properties causes the sediment/water distribution coefficient to be variable. Pore water PRGs would also be appropriate where ecological risks are associated with a contaminated groundwater plume that intersects or is predicted to intersect the bed of a stream or river. The PRGs for these cases are the potential PRGs for aquatic life in surface water (i.e., chronic NAWQCs and secondary chronic values). These values are presented in Table 1, except for those chemicals with aqueous PRGs based on wildlife risks. The values for these chemicals are presented in Table 3, since it is assumed that piscivores do not feed on sediment-associated organisms.

\section{SOIL}

PRGs for soil were chosen by comparing the ORNL toxicological benchmarks for plants, microorganisms, and earthworms in soils to each other and to calculated PRGs for wildlife. ARARs for soils do not exist. Earthworms represent highly exposed invertebrates. Benchmarks for plants appear in Toxicological Benchmarks for Screening Potential Contaminants of Concern for Effects on Terrestrial Plants (Will and Suter 1995b); benchmarks for earthworms and microorganisms appear in Toxicological Benchmarks for Screening Potential Contaminants of Concern for Effects on Soil and Litter Invertebrates and Heterotrophic Process (Will and Suter 1995a). The procedure for calculating PRGs for wildlife endpoints is described in the following paragraphs. All benchmarks and all PRGs are based on one or more field, greenhouse, or growth chamber studies.

Benchmarks for the four types of organisms (wildlife, plants, microorganisms, earthworms) were compared, and the lowest value available is the PRG (Table 4). In media other than soil, if the benchmarks and therefore the PRGs are not exceeded, it is assumed that the chemical concentration in the medium presents no significant ecological hazard. In soils, the uncertainties associated with the PRGs are probably greater than in water or sediments. These uncertainties include:

1. For many chemicals in Table 4, toxicity to only one or two of the three types of organisms (plants, microorganisms, invertebrates) has been studied.

2. Will and Suter $(1995 \mathrm{a}, \mathrm{b})$ have low confidence in most of the soil benchmarks because of a limited number of studies and/or biological endpoints for almost all contaminants. 
3. Soil-earthworm (Sample et al. 1996a) and soil-plant (Efroymson et al. 1996) contaminant uptake factors do not account for soil and biota properties.

Although the confidence in the numbers in Table 4 is generally low, PRGs for soils are needed. As the toxicity of contaminants to additional organisms is investigated, these preliminary values will be modified. PRGs can only be based on toxicity to categories of organisms that have been studied; final remedial goals can incorporate safety factors to protect other populations.

Table 4. Preliminary remediation goals for soils

\begin{tabular}{|c|c|c|}
\hline Chemical & $\begin{array}{l}\text { Soil Concentration } \\
(\mathrm{mg} / \mathrm{kg})\end{array}$ & Endpoint ${ }^{1}$ \\
\hline \multicolumn{3}{|l|}{ Inorganic chemical } \\
\hline Aluminum & $50^{6}$ & plant $^{3}$ \\
\hline Antimony & $5^{6}$ & plant $^{3,4,9}$ \\
\hline Arsenic & 2.66 & shrew \\
\hline Barium & 208 & woodcock \\
\hline Beryllium & $10^{6}$ & plant $^{3,4,9}$ \\
\hline Boron & $0.5^{6}$ & plant $t^{3,9}$ \\
\hline Bromine & $10^{6}$ & plant $^{3,4,9}$ \\
\hline Cadmium & $3^{6}$ & plant \\
\hline Chromium & $0.4^{6}$ & earthworm \\
\hline Cobalt & $20^{6}$ & plant ${ }^{3,9}$ \\
\hline Copper & $50^{7}$ & earthworm \\
\hline Fluorine & $30^{6}$ & microorganism 3,9 \\
\hline Iodine & $4^{6}$ & plant ${ }^{3,4}$ \\
\hline Iron & $200^{6}$ & microorganism $^{23.9}$ \\
\hline Lead & $50^{7}$ & plant \\
\hline Lithium & $2^{6}$ & plant ${ }^{3}$ \\
\hline Manganese & $100^{6}$ & plant $^{3}$ \\
\hline
\end{tabular}


19

Table 4. (continued)

\begin{tabular}{|c|c|c|}
\hline Chemical & $\begin{array}{l}\text { Soil Concentration } \\
(\mathrm{mg} / \mathrm{kg})\end{array}$ & Endpoint ${ }^{1}$ \\
\hline Mercury & 0.0185 & woodcock \\
\hline Molybdenum & $2^{6}$ & plant $^{3}$ \\
\hline Nickel & 24 & woodcock \\
\hline Selenium & 0.79 & shrew \\
\hline Silver & $2^{6}$ & plant ${ }^{9}$ \\
\hline Technetium & $0.2^{6}$ & plant $^{3.49}$ \\
\hline Thallium & $1^{6}$ & plant 3,4 \\
\hline Tin & $50^{6}$ & plant 3.9 \\
\hline Titanium & $1000^{6}$ & microorganism ${ }^{2,3,9}$ \\
\hline Uranium & $5^{6}$ & plant.4 \\
\hline Vanadium & $2^{6}$ & plant $^{3}$ \\
\hline Zinc & 26.3 & woodcock \\
\hline \multicolumn{3}{|l|}{ Organic chemical } \\
\hline Acenaphthene & $20^{6}$ & plant $^{3,49}$ \\
\hline Biphenyl & $60^{6}$ & plant $^{3,49}$ \\
\hline Chlorobenzene & $40^{6}$ & earthworm ${ }^{2,4,9}$ \\
\hline 3-Chlorophenol & $10^{6}$ & earthworm $2.4,9$ \\
\hline Di-n-butyl phthalate & $200^{6}$ & plant $^{3.49}$ \\
\hline 1,4-Dichlorobenzene & $20^{6}$ & earthworm ${ }^{2,4,9}$ \\
\hline 3,4-dichlorophenol & $20^{6}$ & earthworm ${ }^{2,4.9}$ \\
\hline Diethyl phthalate & $100^{6}$ & plant $^{3,49}$ \\
\hline 2,4-Dinitrophenol & $20^{7}$ & plant $3 ., 49$ \\
\hline Furan & $600^{6}$ & plant $^{3.49}$ \\
\hline
\end{tabular}


Table 4. (continued)

\begin{tabular}{|c|c|c|}
\hline Chemical & $\begin{array}{c}\text { Soil Concentration } \\
(\mathrm{mg} / \mathrm{kg})\end{array}$ & Endpoint ${ }^{\prime}$ \\
\hline Hexachlorobenzene & $1000^{6}$ & microorganism ${ }^{3,4,9}$ \\
\hline Hexachlorocyclopentadiene & $10^{6}$ & plant $t^{3,4,9}$ \\
\hline 4-nitrophenol & $7^{6}$ & earthworm ${ }^{2,49}$ \\
\hline Pentachlorophenol & $3^{6}$ & plant \\
\hline Pentachlorobenzene & $20^{6}$ & earthworm ${ }^{2,4,9}$ \\
\hline Phenol & $30^{6}$ & earthworm ${ }^{9}$ \\
\hline PCBs & $40^{6}$ & plant $t^{3,4,9}$ \\
\hline Styrene & $300^{6}$ & plant $^{3,4,9}$ \\
\hline 1,2,3,4-Tetrachlorobenzene & $10^{6}$ & earthworm ${ }^{2,49}$ \\
\hline 2,3,4,5-Tetrachlorophenol & $20^{6}$ & earthworm $2,4,9$ \\
\hline Toluene & $200^{6}$ & plant $t^{3.4,9}$ \\
\hline 1,2,3-Trichlorobenzene & $20^{6}$ & earthworm 24,9 \\
\hline 1,2,4-Trichlorobenzene & $20^{6}$ & earthworm ${ }^{2,4,9}$ \\
\hline 2,4,5-Trichlorophenol & $9^{6}$ & earthworm ${ }^{24.9}$ \\
\hline 2,4,6-Trichlorophenol & $10^{6}$ & earthworm ${ }^{2,49}$ \\
\hline
\end{tabular}

Notes:

1 The most sensitive type of organism among plants, earthworms, and microorganisms. The PRG is based on the toxicological benchmark concentration for this organism and does not consider effects on wildlife.

2 Toxic concentration benchmarks are not available for plants in soils. Therefore, the PRG cannot be assumed to protect plants.

3 Toxic concentration benchmarks are not available for earthworms. Therefore, the PRG cannot be assumed to protect earthworms.

4 Toxic concentration benchmarks are not available for microorganisms. Therefore, the PRG cannot be assumed to protect microorganisms.

5 The benchmark for methyl mercury in plants was compared to benchmarks for total mercury in earthworms and microorganisms.

6 Will and Suter $(1995 \mathrm{a}, \mathrm{b})$ have low confidence in this value. The level of confidence refers to the benchmark chosen for the PRG and not to the relationship between it and the benchmarks not chosen.

7 Will and Suter $(1995 \mathrm{a}, \mathrm{b})$ have moderate confidence in this value.

8 Will and Suter $(1995 \mathrm{a}, \mathrm{b})$ have high confidence in this value.

9 Either soil-plant, soil-earthworm uptake factors or LOAELs were not available. Therefore, the PRG cannot be assumed to protect wildlife. 
Remedial goals for soils should be modified based on the bioavailability of the contaminants of concern. The bioavailable fraction of a chemical in soil is probably lower than the total concentration. Toxicity tests in soil on which the PRGs are based sometimes begin with known concentrations of a chemical or may assume a relationship between what is extractable by an arbitrary solvent and what is bioavailable. The organic fraction and $\mathrm{pH}$ of soil are two major factors that influence the uptake of chemicals by plants. "Aged" organic contaminants may not be as available for uptake as freshly added chemicals. 2,4-Dinitrophenol is an example of a chemical that is more toxic to plants under acidic conditions (Will and Suter 1995b). The context of the studies from which the toxicological benchmarks for soil were derived is available in the Will and Suter reports (1995a,b), Sample et al. (1996b), and in greater detail in the original publications. As more is known about the bioavailability of contaminants in soils, the default PRGs should be modified.

The addition of PRGs to protect terrestrial wildlife is a new feature in this 1996 revision of the PRGs report. Wildlife PRGs for soil were derived by iteratively calculating exposure estimates using different soil concentrations and soil-to-biota contaminant uptake factors for the Oak Ridge Reservation. The soil concentrations were manipulated to produce an exposure estimate equivalent to the wildlife endpoint-specific and contaminant-specific LOAEL, which were obtained from Sample et al. (1996b). Uptake factors for plants were obtained from Efroymson et al. (1996) and for earthworms and small mammals from Sample et al. (1996a). Because different diets may dramatically influence exposures and sensitivity to contaminants varies among species, PRGs were developed for six species present on the Oak Ridge Reservation: short-tailed shrew, white-footed mouse, red fox, white-tailed deer, American woodcock, and red-tailed hawk. The PRGs for each of these species were compared, and the lowest value was selected as the final wildlife PRG. This PRG appears in Table 4 if the concentration in soil is lower than the toxicity benchmarks for earthworms, plants, or soil microbial processes. Estimates of oral exposure to contaminants were generated using the generalized exposure model (Sample and Suter 1994):

$$
E_{j}=\sum_{i=1}^{m} p_{i k}\left(\frac{I R_{i} \times C_{i j k}}{B W}\right)
$$

where:

$E_{j}=$ total exposure to contaminant $(\mathrm{j})(\mathrm{mg} / \mathrm{kg} / \mathrm{d})$,

$\mathrm{m}$ = total number of ingested media (e.g., food or soil),

$\mathrm{IR}_{\mathrm{i}}=$ ingestion rate for medium (i) $(\mathrm{kg} / \mathrm{d}$ or $\mathrm{L} / \mathrm{d})$,

$\mathrm{p}_{\mathrm{ik}}=$ proportion of type $(\mathrm{k})$ of medium (i) consumed (unitless),

$\mathrm{C}_{\mathrm{ijk}}=$ concentration of contaminant $(\mathrm{j})$ in type (k) of medium (i) (mg/kg or mg/L),

$\mathrm{BW}=$ body weight of endpoint species $(\mathrm{kg})$.

PRGs were calculated for only those chemicals for which both uptake factors and LOAELs were available. The 90 th percentile of the soil-to-biota uptake factor was used as a conservative estimate of the chemical concentrations in wildlife food types (earthworms, plants, or small mammals). Species-specific life history parameters needed to estimate exposure were obtained from Sample and Suter (1994) and are presented in Table 5. The model accounts for the ingestion of soil as well as food. Summaries of the derivation of PRGs for each species are presented in the appendix. Soil PRGs for each wildlife species and the recommended final PRG for protection of wildlife, generally, are presented in Table 6. For all chemicals the final PRG for protection of wildlife was based on the PRG for either short-tailed shrew or American woodcock (Table 6). This result is due to the large 
quantity of soil ingested by these wildlife and the relatively high chemical uptake rates for their food (earthworms).

Table 5. Life history parameters used to estimate PRGs for wildlife

\begin{tabular}{|c|c|c|c|c|c|c|}
\hline \multirow[b]{2}{*}{ Species } & \multirow[b]{2}{*}{$\begin{array}{c}\text { Body } \\
\text { Weight } \\
\text { (kg) }\end{array}$} & \multicolumn{2}{|c|}{$\begin{array}{c}\text { Ingestion Rate } \\
(\mathrm{kg} / \mathrm{d})\end{array}$} & \multicolumn{3}{|c|}{ Percent of diet } \\
\hline & & Food & Soil & Earthw'orm & Plant & $\begin{array}{c}\text { Small } \\
\text { Mammal }\end{array}$ \\
\hline Short-tailed Shrew & 0.015 & 0.009 & 0.00117 & $100 \%$ & $0 \%$ & $0 \%$ \\
\hline White-footed Mouse & 0.022 & 0.0034 & 0.000068 & $50 \%$ & $50 \%$ & $0 \%$ \\
\hline Red Fox & 4.5 & 0.45 & 0.0126 & $9 \%$ & $10 \%$ & $81 \%$ \\
\hline White-tailed Deer & 56.5 & 1.74 & 0.0348 & $0 \%$ & $100 \%$ & $0 \%$ \\
\hline American Woodcock & 0.198 & 0.15 & 0.0156 & $100 \%$ & $0 \%$ & $0 \%$ \\
\hline Red-tailed Hawk & 1.126 & 0.109 & 0 & $0 \%$ & $0 \%$ & $100 \%$ \\
\hline
\end{tabular}

Table 6. Summary of species-specific and final soil PRGs for wildlife

\begin{tabular}{|c|c|c|c|c|c|c|c|}
\hline \multirow[b]{2}{*}{ Analyte } & \multicolumn{6}{|c|}{$\begin{array}{c}\text { Preliminary Remedial Goal } \\
(\mathrm{mg} / \mathrm{kg} \text { in soil })\end{array}$} & \multirow[b]{2}{*}{ Final } \\
\hline & Red Fox & $\begin{array}{c}\text { White- } \\
\text { tailed } \\
\text { Deer }\end{array}$ & $\begin{array}{l}\text { White- } \\
\text { footed } \\
\text { Mouse }\end{array}$ & $\begin{array}{c}\text { Short- } \\
\text { tailed } \\
\text { Shrew }\end{array}$ & $\begin{array}{l}\text { American } \\
\text { Woodcock }\end{array}$ & $\begin{array}{l}\text { Red-tailed } \\
\text { Hawk }\end{array}$ & \\
\hline Aluminum & 1040 & 1920 & 1440 & 155 & $N^{2}$ & $\mathrm{ND}^{\mathbf{2}}$ & 155 \\
\hline Arsenic & 32.5 & 119 & 20 & 2.66 & 18.5 & 16500 & 2.66 \\
\hline Barium & 900 & 700 & 1170 & 250 & 208 & 7000 & 208 \\
\hline Cadmium & 62 & 77.5 & 33 & 5.4 & 4.05 & 1570 & 4.05 \\
\hline Chromium & 72 & 1380 & 40.4 & 5.7 & 0.78 & 233 & 0.78 \\
\hline Copper & 143 & 455 & 415 & 77 & 87.5 & 860 & 77 \\
\hline Lead & 5010 & 10100 & 8050 & 1000 & 56 & 2630 & 56 \\
\hline Lithium & 1280 & 3175 & 1670 & 199 & $\mathrm{ND}^{2}$ & $\mathrm{ND}^{a}$ & · 199 \\
\hline Manganese & 19000 & 6800 & 14100 & 4200 & $N^{\mathrm{a}}$ & $\mathrm{ND}^{2}$ & 4200 \\
\hline Mercury & 0.165 & 12.7 & 0.9 & 0.128 & 0.0185 & 0.89 & 0.0185 \\
\hline Molybdenum & 32 & 122 & 16.4 & 2.33 & 21.3 & 36000 & 2.33 \\
\hline Nickel & 560 & 4150 & 345 & 49.5 & 24 & 4750 & 24 \\
\hline Aroclor 1254 & $56^{\mathrm{b}}$ & 138 & 11.8 & 1.47 & 3.27 & $\mathrm{ND}^{\mathrm{b}}$ & 1.47 \\
\hline Aroclor 1260 & 0.88 & 138 & 0.63 & 0.089 & 0.19 & 3.55 & 0.089 \\
\hline
\end{tabular}


Table 6. (continued)

\begin{tabular}{|c|c|c|c|c|c|c|c|}
\hline \multirow[b]{2}{*}{ Analyte } & \multicolumn{6}{|c|}{$\begin{array}{c}\text { Preliminary Remedial Goal } \\
(\mathrm{mg} / \mathrm{kg} \text { in soil })\end{array}$} & \multirow[b]{2}{*}{ Final } \\
\hline & Red Fox & $\begin{array}{l}\text { White- } \\
\text { tailed } \\
\text { Deer }\end{array}$ & $\begin{array}{l}\text { White- } \\
\text { footed } \\
\text { Mouse }\end{array}$ & $\begin{array}{l}\text { Short- } \\
\text { tailed } \\
\text { Shrew }\end{array}$ & $\begin{array}{l}\text { American } \\
\text { Woodcock }\end{array}$ & $\begin{array}{l}\text { Red-tailed } \\
\text { Hawk }\end{array}$ & \\
\hline Selenium & 5.05 & 38 & 5.7 & 0.79 & 0.88 & 44.5 & 0.79 \\
\hline Thallium & 13 & 15.9 & 30.8 & 2.1 & $\mathrm{ND}^{\mathbf{2}}$ & $N^{2}$ & 2.1 \\
\hline Uranium & 505 & 1380 & 800 & 62 & $\mathrm{ND}^{\mathbf{2}}$ & $N^{a}$ & 62 \\
\hline Vanadium & 231 & 170 & 237 & 32.6 & $\mathrm{ND}^{2}$ & $\mathrm{ND}^{\mathrm{a}}$ & 32.6 \\
\hline Zinc & 650 & 3950 & 1140 & 177 & 26.3 & 570 & 26.3 \\
\hline \multicolumn{8}{|c|}{$\begin{array}{l}\text { Notes: } \\
\text { ND = LOAEL for birds not available for these chemicals. } \\
\text { Soil-small mammal uptake factor not available. Red fox available from soil only. PRG for red-tailed hawk } \\
\text { could not be calculated because soil ingestion }=0 \text {; }\end{array}$} \\
\hline \multicolumn{8}{|c|}{$\begin{array}{l}\text { PRGs for soil, more than for other media, are likely to be influenced by different land use } \\
\text { scenarios. Uses of soil will affect the fraction of land that is suitable for habitat and the necessity of } \\
\text { protecting various organisms. The PRGs in Table } 4 \text { and the calculations for wildlife assume that } \\
\text { habitat is } 100 \% \text { available for the organisms in the assessed region. This assumption is reasonable } \\
\text { for relatively immobile organisms such as plants, earthworms, and microorganisms. However, for } \\
\text { wildlife, the role of habitat will be important for determining exposure. For example, if the } \\
\text { availability of habitat at a site is minimal, use of the site by wildlife, and therefore contaminant } \\
\text { exposure, is likely to be minimal. }\end{array}$} \\
\hline
\end{tabular}

\section{REFERENCES}

Efroymson, R. A., B. E. Sample, G. W. Suter II, and T. L. Ashwood. 1996. Soil-plant Uptake Factors: Review and Recommendations for the Oak Ridge Reservation. ES/ER/TM-198. Oak Ridge National Laboratory, Oak Ridge, Tennessee.

Energy Systems (Lockheed Martin Energy Systems, Inc.). 1995. Preliminary remediation goals for use at the U. S. Department of Energy Oak Ridge Operations Office, ES/ER/TM-106, Risk Assessment Program, Health Sciences Research Division, Oak Ridge National Laboratory, Oak Ridge, Tennessee.

EPA (United States Environmental Protection Agency). 1989. Briefing report to the EPA Science Advisory Board on the Equilibrium Partitioning Approach to Generating Sediment Quality.

EPA. 1991. Risk Assessment Guidance for Superfund: Volume I - Human Health Evaluation Manual (Part B, Development of Risk-based Preliminary Remediation Goals), Office of Emergency and Remedial Response, U.S. Environmental Protection Agency, Washington, D.C. Pub. 9285.7$01 \mathrm{~B}$.

EPA. 1993a. Water quality guidance for the Great Lakes System and correction; Proposed rules, Federal Register 58(72):20802-21047. 
EPA. 1993b. Sediment Quality Criteria for the Protection of Benthic Organisms: Acenaphthene., EPA-822-R-93-013, United States Environmental Protection Agency, Washington, D. C.

EPA. 1993c. Sediment Quality Criteria for the Protection of Benthic Organisms: Dieldrin, EPA822-R-93-015, United States Environmental Protection Agency, Washington, D. C.

EPA. 1993d. Sediment Quality Criteria for the Protection of Benthic Organisms: Endrin, EPA-822R-93-016, United States Environmental Protection Agency, Washington, D. C.

EPA. 1993e. Sediment Quality Criteria for the Protection of Benthic Organisms: Fluoranthene., EPA-822-R-93-012, United States Environmental Protection Agency, Washington, D. C.

EPA. 1993f. Sediment Quality Criteria for the Protection of Benthic Organisms: Phenanthrene, EPA-822-R-93-014, United States Environmental Protection Agency, Washington, D. C.

Etnier, E. L., E. P. McDonald, and L. M. Houlberg. 1993. Applicable or relevant and appropriate requirements (ARARs) for remedial action at the Oak Ridge Reservation: A compendium of environmental laws, ES/ER/TM-1/R2, Oak Ridge National Laboratory, Oak Ridge, Tennessee.

Jones, D. S., R. N. Hull, and G. W. Suter II. 1996. Toxicological Benchmarks for Screening Contaminants of Potential Concern for Effects on Sediment-associated Biota: 1996 Revision, ES/ER/TM-95/R2, Oak Ridge National Laboratory, Oak Ridge, Tennessee.

Long, E. R. and L. G. Morgan. 1990. The potential for biological effects of sediment-sorbed contaminants tested in the National Status and Trends Program, NOAA Technical Memorandum NOS OMA 58, National Oceanic and Atmospheric Administration, Seattle, Washington.

Long, E. R., D. D. MacDonald, S. L. Smith, and F. D. Calder. 1995. Incidence of Adverse Biological Effects within Ranges of Chemical Concentrations in Marine and Estuarine Sediments. Environmental Management 19(1), 81-97.

MacDonald, D. D., MacDonald Environmental Services Ltd. November 1994a. Approach to the assessment of sediment quality in Florida coastal waters. Vol. 2 - Application of the sediment quality assessment guidelines, Florida Department of Environmental Protection, Office of Water Policy, Tallahassee, Florida.

MacDonald, D. D., MacDonald Environmental Services Ltd. November 1994b. Approach to the assessment of sediment quality in Florida coastal waters. Vol. 3 - Supporting documentation: Biological effects database for sediments, Florida Department of Environmental Protection, Office of Water Policy, Tallahassee, Florida.

Sample, B. E.., D. M. Opresko, and G. W. Suter II. 1996. Toxicological Benchmarks for Wildlife: 1996 Revision, ES/ER/TM-86/R3, Oak Ridge National Laboratory, Oak Ridge, Tennessee.

Sample, B. E., and G. W. Suter II. 1994a. Estimating Exposure of Terrestrial Wildlife to Contaminants. ES/ER/TM-125, Oak Ridge National Laboratory, Oak Ridge, Tennessee. 
Sample, B. E., R. A. Efroymson, G. W. Suter II, and T. L. Ashwood. 1996b. Soil-earthworm and Soil-small mammal Contaminant Uptake Factors: Review and Recommendations for the Oak Ridge Reservation. ES/ER/TM-197. Oak Ridge National Laboratory, Oak Ridge, Tennessee.

Stephan, C. E., D. I. Mount, D. J. Hansen, J. H. Gentile, G. A. Chapman, and W. A. Brungs. 1985. Guidelines for deriving numerical national water quality criteria for the protection of aquatic organisms and their uses, PB85-227049, National Technical Information Service, Springfield, Virginia.

Suter, G. W. II, B. E. Sample, D. S. Jones, T. L. Ashwood, and J. M. Loar. 1995. Approach and Strategy for Performing Ecological Risk Assessments for the U. S. Department of Energy's Oak Ridge Reservation: 1995 Revision, ES/ER/TM-33/R2, Oak Ridge National Laboratory, Oak Ridge, Tennessee.

Suter, G. W. II and C. L. Tsao. 1996. Toxicological Benchmarks for Screening Potential Contaminants of Concern for Effects on Aquatic Biota: 1996 Revision, ES/ER/TM-96/R2, Oak Ridge National Laboratory, Oak Ridge, Tennessee.

Will, M. E. and G. W. Suter II. 1995a. Toxicological Benchmarks for Screening Potential Contaminants of Concern for Effects on Soil and Litter Invertebrates and Heterotrophic Process: 1995 Revision, ES/ER/TM-126/RI, Oak Ridge National Laboratory, Oak Ridge, Tennessee.

Will, M. E. and G. W. Suter II. 1995b. Toxicological Benchmarks for Screening Potential Contaminants of Concern for Effects on Terrestrial Plants: 1995 Revision, ES/ER/TM-85/R2, Oak Ridge National Laboratory, Oak Ridge, Tennessee. 

APPENDIX 



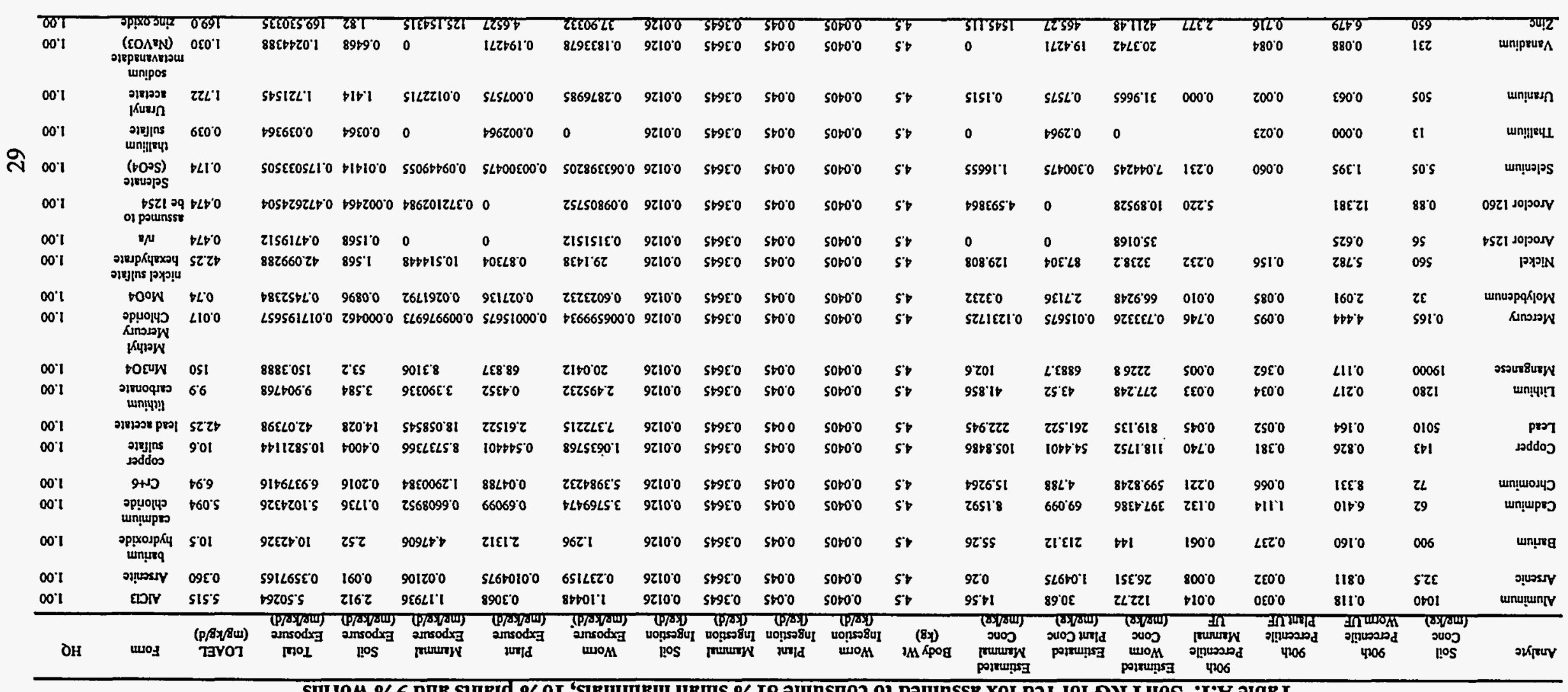


Table A.2. Soil PRG for white-tailed deer assumed to consume $100 \%$ plants

\begin{tabular}{|c|c|c|c|c|c|c|c|c|c|c|c|c|}
\hline Analyte & $\begin{array}{c}\text { Soil } \\
\text { Conc } \\
(\mathrm{mg} / \mathrm{kg})\end{array}$ & $\begin{array}{c}\text { 90th } \\
\text { Percentile } \\
\text { Plant UF }\end{array}$ & $\begin{array}{l}\text { Estimated } \\
\text { Plant Conc } \\
\text { (me/kg) }\end{array}$ & $\begin{array}{c}\text { Body Wt } \\
(\mathrm{kg})\end{array}$ & $\begin{array}{c}\text { Food } \\
\text { Ingestion } \\
(\mathrm{kg} / \mathrm{d})\end{array}$ & $\begin{array}{c}\text { Soil } \\
\text { Ingestion } \\
\text { (kg/d) }\end{array}$ & $\begin{array}{c}\text { Food } \\
\text { Exposure } \\
(\mathrm{m} / \mathrm{kg} / \mathrm{d})\end{array}$ & $\begin{array}{c}\text { Soil } \\
\text { Exposure } \\
(\mathrm{m} / \mathrm{k} / \mathrm{d})\end{array}$ & $\begin{array}{c}\text { Total } \\
\text { Exposure } \\
(\mathrm{mo} / \mathrm{kg} / \mathrm{d})\end{array}$ & $\begin{array}{c}\text { LOAEL } \\
(\mathrm{m} / \mathrm{kg} / \mathrm{d})\end{array}$ & Form & HQ \\
\hline Aluminum & 1920 & 0.030 & 56.64 & 56.5 & 1.74 & 0.0348 & 1.744311504 & 1.18258407 & 2.92689558 & 2.930 & $\mathrm{AlCl} 3$ & 1.00 \\
\hline Arsenic & 119 & 0.032 & 3.8437 & 56.5 & 1.74 & 0.0348 & 0.118372354 & 0.0732956 & 0.19166793 & 0.191 & Arsenite & 1.00 \\
\hline Barium & 700 & 0.237 & 165.76 & 56.5 & 1.74 & 0.0348 & 5.104821239 & 0.43115044 & 5.53597168 & 5.6 & $\begin{array}{l}\text { barium } \\
\text { hydroxide }\end{array}$ & 1.00 \\
\hline Cadmium & 77.5 & 1.115 & 86.37375 & 56.5 & 1.74 & 0.0348 & 2.660005752 & 0.0477345 & 2.70774027 & 2.706 & $\begin{array}{l}\text { cadmium } \\
\text { chloride }\end{array}$ & 1.00 \\
\hline Chromium & 1380 & 0.067 & 91.77 & 56.5 & 1.74 & 0.0348 & 2.82619115 & 0.8499823 & 3.67617345 & 3.69 & $\mathrm{Cr}+6$ & 1.00 \\
\hline Copper & 455 & 0.381 & 173.2185 & 56.5 & 1.74 & 0.0348 & 5.334516637 & 0.28024779 & 5.61476442 & 5.6 & $\begin{array}{l}\text { copper } \\
\text { sulfate }\end{array}$ & 1.00 \\
\hline Lead & 10100 & 0.052 & 527.22 & 56.5 & 1.74 & 0.0348 & 16.23650973 & 6.22088496 & 22.4573947 & 22.44 & lead acetate & 1.00 \\
\hline Lithium & 3175 & 0.034 & 107.95 & 56.5 & 1.74 & 0.0348 & 3.324477876 & 1.95557522 & 5.2800531 & 5.3 & $\begin{array}{l}\text { lithium } \\
\text { carbonate }\end{array}$ & 1.00 \\
\hline Manganese & 6800 & 0.362 & 2463.64 & 56.5 & 1.74 & 0.0348 & 75.87139115 & 4.18831858 & 80.0597097 & 80 & $\mathrm{Mn3O4}$ & 1.00 \\
\hline Mercury & 12.7 & 0.095 & 1.2065 & 56.5 & 1.74 & 0.0348 & 0.03715593 & 0.007822 & 0.0449782 & 0.045 & $\begin{array}{l}\text { Methyl } \\
\text { Mercury } \\
\text { Chloride }\end{array}$ & 1.00 \\
\hline Molybdenum & 122 & 0.085 & 10.3456 & 56.5 & 1.74 & 0.0348 & 0.318607858 & 0.0751434 & 0.39375122 & 0.39 & $\mathrm{MoO} 4$ & 1.00 \\
\hline Nickel & 4150 & 0.156 & 646.985 & 56.5 & 1.74 & 0.0348 & 19.92484779 & 2.55610619 & 22.480954 & 22.44 & $\begin{array}{c}\text { nickel } \\
\text { sulfate } \\
\text { hexahydrat } \\
\text { e }\end{array}$ & 1.00 \\
\hline Aroclor 1254 & 138 & & 0 & 56.5 & 1.74 & 0.0348 & 0 & 0.0849982 & 0.0849982 & 0.085 & $\mathbf{n} / \mathbf{a}$ & 1.00 \\
\hline Aroclor 1260 & 138 & & 0 & 56.5 & 1.74 & 0.0348 & 0 & 0.0849982 & 0.0849982 & 0.085 & $\begin{array}{l}\text { assumed to } \\
\text { be } 1254\end{array}$ & 1.00 \\
\hline Selenium & 38 & 0.060 & 2.261 & 56.5 & 1.74 & 0.0348 & 0.0696308 & 0.0234053 & 0.0930361 & 0.093 & $\begin{array}{l}\text { Selenate } \\
(\mathrm{SeO} 4)\end{array}$ & 1.00 \\
\hline Thallium & 15.9 & 0.023 & 0.36252 & 56.5 & 1.74 & 0.0348 & 0.01116433 & 0.009793 & 0.0209576 & 0.021 & $\begin{array}{l}\text { thallium } \\
\text { sulfate }\end{array}$ & 1.00 \\
\hline Uranium & 1380 & 0.002 & 2.07 & 56.5 & 1.74 & 0.0348 & 0.06374867 & 0.8499823 & 0.91373097 & 0.915 & $\begin{array}{l}\text { Uranyl } \\
\text { acetate }\end{array}$ & 1.00 \\
\hline Vanadium & $\$ 70$ & 0.084 & 14.297 & 56.5 & 1.74 & 0.0348 & 0.440295991 & 0.10470796 & 0.54500496 & 0.547 & $\begin{array}{c}\text { sodium } \\
\text { metavanad } \\
\text { ate } \\
\text { (NavO3) }\end{array}$ & 1.00 \\
\hline Zinc & 3950 & 0.716 & 2827.41 & 56.5 & 1.74 & 0.0348 & 87.07421947 & 2.43292035 & 89.5071398 & 89.8 & zinc oxide & 1.00 \\
\hline
\end{tabular}


Table A.3. Soil PRG for white-footed mice assumed to consume $50 \%$ plants and $50 \%$ worms

\begin{tabular}{|c|c|c|c|c|c|c|c|c|c|c|c|c|c|c|c|c|}
\hline Analyte & $\begin{array}{c}\text { Soil } \\
\text { Conc } \\
\text { (me/kg) }\end{array}$ & $\begin{array}{c}\text { 90th } \\
\text { Percentile } \\
\text { Worm UF }\end{array}$ & $\begin{array}{c}\text { 90th } \\
\text { Percentile } \\
\text { Plant UF }\end{array}$ & $\begin{array}{c}\text { Estimated } \\
\text { Worm Cone } \\
(\mathrm{mg} / \mathrm{kg})\end{array}$ & $\begin{array}{l}\text { Estimated } \\
\text { Plant Cone } \\
\text { (me/ke) }\end{array}$ & $\begin{array}{c}\text { Body Wt } \\
(\mathrm{kQ})\end{array}$ & $\begin{array}{c}\text { Worm } \\
\text { Ingestion } \\
\text { (ke/d) }\end{array}$ & $\begin{array}{c}\text { Plant } \\
\text { Ingestion } \\
\text { (kg/d) }\end{array}$ & $\begin{array}{c}\text { Soil } \\
\text { Ingestion } \\
\text { (k\&/d) }\end{array}$ & $\begin{array}{c}\text { Worm } \\
\text { Exposure } \\
(\mathrm{mg} / \mathrm{kg} / \mathrm{d})\end{array}$ & $\begin{array}{c}\text { plant } \\
\text { Exposure } \\
\text { (me/ko/d) }\end{array}$ & $\begin{array}{c}\text { Soil } \\
\text { Exposure } \\
\text { (me/ke/d) }\end{array}$ & $\begin{array}{c}\text { Total } \\
\text { Exposure } \\
\text { (mo/kg/d) }\end{array}$ & $\begin{array}{c}\text { LOAEL } \\
\text { (me/kg/d) }\end{array}$ & Form & HQ \\
\hline Aluminum & 1440 & 0.118 & 0.030 & 169.92 & 42.48 & 0.022 & 0.0017 & 0.0017 & 0.000068 & 13.13018182 & 3.282545455 & 4.450909091 & 20.86363636 & 20.856 & $\mathrm{AlCl} 3$ & 1.00 \\
\hline Arsenic & 20 & 0.811 & 0.032 & 16.216 & 0.646 & 0.022 & 0.0017 & 0.0017 & 0.000068 & 1.253054545 & 0.049918182 & 0.061818182 & 1.364790909 & 1.362 & Arsenite & 1.00 \\
\hline Barium & 1170 & 0.160 & 0.237 & 187.2 & 277.056 & 0.022 & 0.0017 & 0.0017 & 0.000068 & 14.46545455 & 21.40887273 & 3.616363636 & 39.49069091 & 39.5 & $\begin{array}{c}\text { barium } \\
\text { hydroxide }\end{array}$ & 1.00 \\
\hline Cadmium & 33 & 6.410 & 1.114 & 211.5399 & 36.7785 & 0.022 & 0.0017 & 0.0017 & 0.000068 & 16.346265 & 2.841975 & 0.102 & 19.29024 & 19.264 & $\begin{array}{l}\text { cadmium } \\
\text { chloride }\end{array}$ & 1.00 \\
\hline Chromium & 40.4 & 8.331 & 0.066 & 336.56836 & 2.6866 & 0.022 & 0.0017 & 0.0017 & 0.000068 & 26.00755509 & 0.207600909 & 0.124872727 & 26.34002873 & 26.24 & $\mathrm{Cr}+6$ & 1.00 \\
\hline Copper & 415 & 0.826 & 0.381 & 342.956 & 157.9905 & 0.022 & 0.0017 & 0.0017 & 0.000068 & 26.50114545 & 12.20835682 & 1.282727273 & 39.99222955 & 40.0 & $\begin{array}{l}\text { copper } \\
\text { sulfate }\end{array}$ & 1.00 \\
\hline Lead & 8050 & 0.164 & 0.052 & 1316.175 & 420.21 & 0.022 & 0.0017 & 0.0017 & 0.000068 & 101.7044318 & 32.47077273 & 24.88181818 & 159.0570227 & 159.77 & lead acctate & 1.00 \\
\hline Lithium & 1670 & 0.217 & 0.034 & 361.722 & 56.78 & 0.022 & 0.0017 & 0.0017 & 0.000068 & 27.95124545 & 4.387545455 & 5.161818182 & 37.50060909 & 37.5 & $\begin{array}{c}\text { lithium } \\
\text { carbonate }\end{array}$ & 1.00 \\
\hline Manganese & 14100 & 0.117 & 0.362 & 1652.52 & 5108.43 & 0.022 & 0.0017 & 0.0017 & 0.000068 & 127.6947273 & 394.7423182 & 43.58181818 & 566.0188636 & 567 & $\mathrm{Mn} 304$ & 1.00 \\
\hline & & & & & & & & & & & & & & & $\begin{array}{l}\text { Methyl } \\
\text { Mercury }\end{array}$ & \\
\hline Mercury & 0.9 & 4.444 & 0.095 & 3.99996 & 0.0855 & 0.022 & 0.0017 & 0.0017 & 0.000068 & 0.309087818 & 0.006606818 & 0.002781818 & 0.318476455 & 0.320 & Chloride & 1.00 \\
\hline Molybdenum & 16.4 & 2.091 & 0.085 & 34.29896 & 1.39072 & 0.022 & 0.0017 & 0.0017 & 0.000068 & 2.650374182 & 0.107464727 & 0.050690909 & 2.808529818 & 2.81 & $\mathrm{MoO4}$ & 1.00 \\
\hline Nickel & 345 & 5.782 & 0.156 & 1994.9625 & 53.7855 & 0.022 & 0.0017 & 0.0017 & 0.000068 & 154.1561932 & 4.156152273 & 1.066363636 & 159.3787091 & 159.77 & $\begin{array}{l}\text { nickel sulfate } \\
\text { hexahydrate }\end{array}$ & 1.00 \\
\hline Aroclor 1254 & 11.8 & 0.625 & & 7.37854 & 0 & 0.022 & 0.0017 & 0.0017 & 0.000068 & 0.570159909 & 0 & 0.036472727 & 0.606632636 & 0.607 & $\mathbf{n} / \mathbf{a}$ & 1.00 \\
\hline Aroclor 1260 & 0.63 & 12.381 & & 7.80003 & 0 & 0.022 & 0.0017 & 0.0017 & 0.000068 & 0.602729591 & 0 & 0.001947273 & 0.604676864 & 0.607 & $\begin{array}{l}\text { assumed to } \\
\text { be } 1254\end{array}$ & 1.00 \\
\hline Selenium & 5.7 & 1.395 & 0.060 & 7.95093 & 0.33915 & 0.022 & 0.0017 & 0.0017 & 0.000068 & 0.614390045 & 0.026207045 & 0.017618182 & 0.658215273 & 0.659 & $\begin{array}{l}\text { Selenate } \\
(\mathrm{SeO})\end{array}$ & 1.00 \\
\hline Thallium & 30.8 & 0.000 & 0.023 & 0 & 0.70224 & 0.022 & 0.0017 & 0.0017 & 0.000068 & 0 & 0.054264 & 0.0952 & 0.149464 & 0.149 & $\begin{array}{l}\text { thallium } \\
\text { sulfate }\end{array}$ & 1.00 \\
\hline Uranium & 800 & 0.063 & 0.002 & 50.64 & 1.2 & 0.022 & 0.0017 & 0.0017 & 0.000068 & 3.913090909 & 0.092727273 & 2.472727273 & 6.478545455 & 6.511 & $\begin{array}{l}\text { Uranyl } \\
\text { acetate }\end{array}$ & 1.00 \\
\hline & & & & & & & & & & & & & & & $\begin{array}{c}\text { sodium } \\
\text { metavanadat }\end{array}$ & \\
\hline Vanadium & 237 & 0.088 & 0.084 & 20.9034 & 19.9317 & 0.022 & 0.0017 & 0.0017 & 0.000068 & 1.615262727 & 1.540176818 & 0.732545455 & 3.887985 & 3.894 & c (NaVO3) & 1.00 \\
\hline Zinc & 1140 & 6.479 & 0.716 & 7386.288 & 816.012 & 0.022 & 0.0017 & 0.0017 & 0,000068 & 570.7586182 & 63.05547273 & 3.523636364 & 637.3377273 & 639.1 & zinc oxide & 1.00 \\
\hline
\end{tabular}


Table A.4. Soil PRG for short-tailed shrews assumed to consume $100 \%$ worms

\begin{tabular}{|c|c|c|c|c|c|c|c|c|c|c|c|c|}
\hline Analyte & $\begin{array}{c}\text { Soil } \\
\text { Conc } \\
(\mathrm{mg} / \mathrm{kg})\end{array}$ & $\begin{array}{c}\text { 90th } \\
\text { Percentile } \\
\text { Worm UF } \\
\end{array}$ & $\begin{array}{l}\text { Estimated } \\
\text { Worm Conc } \\
(\mathrm{mg} / \mathrm{kg})\end{array}$ & $\begin{array}{c}\text { Body Wt } \\
\text { (kg) }\end{array}$ & $\begin{array}{c}\text { Food } \\
\text { Ingestion } \\
\text { (kg/d) }\end{array}$ & $\begin{array}{c}\text { Soil } \\
\text { Ingestion } \\
\text { (kg/d) }\end{array}$ & $\begin{array}{c}\text { Food } \\
\text { Exposure } \\
(\mathrm{mg} / \mathrm{kg} / \mathrm{d})\end{array}$ & $\begin{array}{c}\text { Soil } \\
\text { Exposure } \\
\text { (mg/kg/d) }\end{array}$ & $\begin{array}{c}\text { Total } \\
\text { Exposure } \\
\text { (mg/kg/d) }\end{array}$ & $\begin{array}{l}\text { LOAEL } \\
(\mathrm{mg} / \mathrm{kg} / \mathrm{d})\end{array}$ & Form & HQ \\
\hline Aluminum & 155 & 0.118 & 18.29 & 0.015 & 0.009 & 0.00117 & 10.974 & 12.09 & 23.064 & 22.952 & $\mathrm{AlCl} 3$ & 1.00 \\
\hline Arsenic & 2.66 & 0.811 & 2.156728 & 0.015 & 0.009 & 0.00117 & 1.2940368 & 0.20748 & 1.5015168 & 1.498 & $\begin{array}{l}\text { Arsenite } \\
\text { barium }\end{array}$ & 1.00 \\
\hline Barium & 250 & 0.160 & 40 & 0.015 & 0.009 & 0.00117 & 24 & 19.5 & 43.5 & 43.5 & hydroxide & 1.00 \\
\hline Cadmium & 5.4 & 6.410 & 34.61562 & 0.015 & 0.009 & 0.00117 & 20.769372 & 0.4212 & 21.190572 & 21.200 & $\begin{array}{l}\text { cadmium } \\
\text { chloride }\end{array}$ & 1.00 \\
\hline Chromium & 5.7 & 8.331 & 47.48613 & 0.015 & 0.009 & 0.00117 & 28.491678 & 0.4446 & 28.936278 & 28.88 & $\mathrm{Cr}+6$ & 1.00 \\
\hline Copper & 77 & 0.826 & 63.6328 & 0.015 & 0.009 & 0.00117 & 38.17968 & 6.006 & 44.18568 & 44.0 & $\begin{array}{l}\text { copper } \\
\text { sulfate }\end{array}$ & 1.00 \\
\hline Lead & 1000 & 0.164 & 163.5 & 0.015 & 0.009 & 0.00117 & 98.1 & 78 & 176.1 & 175.83 & lead acetate & 1.00 \\
\hline Lithium & 199 & 0.217 & 43.1034 & 0.015 & 0.009 & 0.00117 & 25.86204 & 15.522 & 41.38404 & 41.3 & $\begin{array}{l}\text { lithium } \\
\text { carbonate }\end{array}$ & 1.00 \\
\hline Manganese & 4200 & 0.117 & 492.24 & 0.015 & 0.009 & 0.00117 & 295.344 & 327.6 & 622.944 & 624 & Mn3O4 & 1.00 \\
\hline & & & & & & & & & & & $\begin{array}{l}\text { Methyl } \\
\text { Mercury }\end{array}$ & \\
\hline Mercury & 0.128 & 4.444 & 0.5688832 & 0.015 & 0.009 & 0.00117 & 0.34132992 & 0.009984 & 0.35131392 & 0.352 & Chloride & 1.00 \\
\hline Molybdenum & 2.33 & 2.091 & 4.872962 & 0.015 & 0.009 & 0.00117 & 2.9237772 & 0.18174 & 3.1055172 & 3.09 & $\mathrm{MoO} 4$ & 1.00 \\
\hline & & & & & & & & & & & $\begin{array}{l}\text { nickel } \\
\text { sulfate }\end{array}$ & \\
\hline Nickel & 49.5 & 5.783 & 286.23375 & 0.015 & 0.009 & 0.00117 & 171.74025 & 3.861 & 175.60125 & 175.83 & hexahydrate & 1.00 \\
\hline Aroclor 1254 & 1.47 & 0.625 & 0.919191 & 0.015 & 0.009 & 0.00117 & 0.5515146 & 0.11466 & 0.6661746 & 0.668 & $n / a$ & 1.00 \\
\hline Aroclor 1260 & 0.089 & 12.381 & 1.101909 & 0.015 & 0.009 & 0.00117 & 0.6611454 & 0.006942 & 0.6680874 & $0.668 \mathrm{~b}$ & $\begin{array}{l}\text { assumed to } \\
\text { be } 1254\end{array}$ & 1.00 \\
\hline Selenium & 0.79 & 1.395 & 1.101971 & 0.015 & 0.009 & 0.00117 & 0.6611826 & 0.06162 & 0.7228026 & 0.725 & $\begin{array}{l}\text { Selenate } \\
(\mathrm{SeO})\end{array}$ & 1.00 \\
\hline Thallium & 2.1 & 0.000 & 0 & 0.015 & 0.009 & 0.00117 & 0 & 0.1638 & 0.1638 & 0.164 & $\begin{array}{l}\text { thallium } \\
\text { sulfate }\end{array}$ & 1.00 \\
\hline Uranium & 62 & 0.063 & 3.9246 & 0.015 & 0.009 & 0.00117 & 2.35476 & 4.836 & 7.19076 & 7.165 & $\begin{array}{c}\text { Uranyl } \\
\text { acetate } \\
\text { sodium } \\
\text { metavanadat }\end{array}$ & 1.00 \\
\hline Vanadium & 32.6 & 0.088 & 2.87532 & 0.015 & 0.009 & 0.00117 & 1.725192 & 2.5428 & 4.267992 & 4.285 & e (NaVO3) & 1.00 \\
\hline Zinc & 177 & 6.479 & 1146.8184 & 0.015 & 0.009 & 0.00117 & 688.09104 & 13.806 & 701.89704 & 703.3 & zinc oxide & 1.00 \\
\hline
\end{tabular}


Table A.5. Soil PRG for american woodcock assumed to consume $100 \%$ worms

\begin{tabular}{|c|c|c|c|c|c|c|c|c|c|c|c|c|}
\hline Analyte & $\begin{array}{c}\text { Soil } \\
\text { Conc } \\
(\mathrm{mg} / \mathrm{kg})\end{array}$ & $\begin{array}{c}\text { 90th } \\
\text { Percentile } \\
\text { Worm UF } \\
\end{array}$ & $\begin{array}{c}\text { Estimated } \\
\text { Worm Conc } \\
(\mathrm{mg} / \mathrm{kg})\end{array}$ & $\begin{array}{c}\text { Body Wt } \\
(\mathrm{kg})\end{array}$ & $\begin{array}{c}\text { Food } \\
\text { Ingestion } \\
\text { (kg/d) }\end{array}$ & $\begin{array}{c}\text { Soil } \\
\text { Ingestion } \\
\text { (kg/d) }\end{array}$ & $\begin{array}{c}\text { Food } \\
\text { Exposure } \\
\text { (mg/kg/d) }\end{array}$ & $\begin{array}{c}\text { Soil } \\
\text { Exposure } \\
\text { (me/kg/d) }\end{array}$ & $\begin{array}{c}\text { Total } \\
\text { Exposure } \\
\text { (mg/kg/d) }\end{array}$ & $\begin{array}{c}\text { LOAEL } \\
(\mathrm{mg} / \mathrm{kg} / \mathrm{d})\end{array}$ & Form & HQ \\
\hline Aluminum & & 0.118 & 0 & 0.198 & 0.15 & 0.0156 & 0 & $\mathbf{0}$ & $\mathbf{0}$ & 0.0 & $\mathrm{Al} 2(\mathrm{SO} 4) 2$ & \#DIV/O! \\
\hline Arsenic & 18.5 & 0.811 & 14.9998 & 0.198 & 0.15 & 0.0156 & 11.36348485 & 1.457575758 & 12.82106061 & 12.8 & sodium arsenite & 1.00 \\
\hline Barium & 208 & 0.160 & 33.28 & 0.198 & 0.15 & 0.0156 & 25.21212121 & 16.38787879 & 41.6 & 41.7 & barium hydroxide & 1.00 \\
\hline Cadmium & 4.05 & 6.410 & 25.961715 & 0.198 & 0.15 & 0.0156 & 19.66796591 & 0.319090909 & 19.98705682 & 20.00 & cadmium chloride & 1.00 \\
\hline Chromium & 0.78 & 8.331 & 6.498102 & 0.198 & 0.15 & 0.0156 & 4.922804545 & 0.061454545 & 4.984259091 & 5.00 & $\mathrm{Cr}+3$ as $\mathrm{CrK}(\mathrm{SO} 4) 2$ & 1.00 \\
\hline Copper & 87.5 & 0.826 & 72.31 & 0.198 & 0.15 & 0.0156 & 54.78030303 & 6.893939394 & 61.67424242 & 61.7 & copper oxide & 1.00 \\
\hline Lead & 56 & 0.164 & 9.156 & 0.198 & 0.15 & 0.0156 & 6.936363636 & 4.412121212 & 11.34848485 & 11.30 & lead acetate & 1.00 \\
\hline Lithium & & 0.217 & 0 & 0.198 & 0.15 & 0.0156 & 0 & 0 & 0 & & & \#DIV/0I \\
\hline Manganese & & 0.117 & 0 & 0.198 & 0.15 & 0.0156 & 0 & 0 & 0 & 0 & $\mathrm{Mn} 3 \mathrm{O} 4$ & \#DIVI0! \\
\hline Mercury & 0.0185 & 4.444 & 0.0822214 & 0.198 & 0.15 & 0.0156 & 0.062288939 & 0.001457576 & 0.063746515 & 0.064 & $\begin{array}{l}\text { Methyl Mercury } \\
\text { Dicyandiamide }\end{array}$ & 1.00 \\
\hline $\begin{array}{l}\text { Molybdenu } \\
\mathrm{m}\end{array}$ & 21.3 & 2.091 & 44.54682 & 0.198 & 0.15 & 0.0156 & 33.74759091 & 1.678181818 & 35.42577273 & 35.30 & $\begin{array}{l}\text { sodium molybdate } \\
(\mathrm{MOO4})\end{array}$ & 1.00 \\
\hline Nicke! & 24 & 5.782 & 138.78 & 0.198 & 0.15 & 0.0156 & 105.1363636 & 1.890909091 & 107.0272727 & 107.00 & nickel sulfate & 1.00 \\
\hline PCB-1254 & 3.27 & 0.625 & 2.044731 & 0.198 & 0.15 & 0.0156 & 1.549038636 & 0.257636364 & 1.806675 & 1.800 & $n / a$ & 1.00 \\
\hline PCB-1260 & 0.19 & 12.381 & 2.35239 & 0.198 & 0.15 & 0.0156 & 1.782113636 & 0.014969697 & 1.797083333 & 1.800 & ssumed to be 1254 & 1.00 \\
\hline Selenium & 0.88 & 1.395 & 1.227512 & 0.198 & 0.15 & 0.0156 & 0.9299333333 & 0.069333333 & 0.999266667 & 1.000 & sodium selenite & 1.00 \\
\hline Thallium & & 0.000 & 0 & 0.198 & 0.15 & 0.0156 & 0 & 0 & 0 & & & \#DIV/0! \\
\hline Uranium & & 0.063 & 0 & 0.198 & 0.15 & 0.0156 & 0 & 0 & 0 & 0.0 & depleted metalic U & HDIV/0! \\
\hline Vanadium & & 0.088 & 0 & 0.198 & 0.15 & 0.0156 & 0 & 0 & 0 & 0.000 & vanadyl sulfate & \#DIV/0! \\
\hline Zinc & 26.3 & 6.479 & 170.40296 & 0.198 & 0.15 & 0.0156 & 129.0931515 & 2.072121212 & 131.1652727 & 131.0 & zinc sulfate & 1.00 \\
\hline
\end{tabular}


Table A.6. Soil PRG for red-tailed hawk assumed to consume $100 \%$ small mammals

\begin{tabular}{|c|c|c|c|c|c|c|c|c|c|c|c|c|}
\hline Analyte & $\begin{array}{c}\text { Soil } \\
\text { Conc } \\
(\mathrm{mg} / \mathrm{kg})\end{array}$ & $\begin{array}{c}\text { 90th } \\
\text { Percentile } \\
\text { Mammal UF }\end{array}$ & $\begin{array}{c}\text { Estimated } \\
\text { Mammal } \\
\text { Conc } \\
(\mathrm{mg} / \mathrm{kg})\end{array}$ & $\begin{array}{c}\text { Body Wt } \\
(\mathrm{kg})\end{array}$ & $\begin{array}{c}\text { Food } \\
\text { Ingestion } \\
(\mathrm{kg} / \mathrm{d}) \\
\end{array}$ & $\begin{array}{c}\text { Soil } \\
\text { Ingestion } \\
\text { (kg/d) }\end{array}$ & $\begin{array}{c}\text { Food } \\
\text { Exposure } \\
(\mathrm{mg} / \mathrm{kg} / \mathrm{d})\end{array}$ & $\begin{array}{c}\text { Soil } \\
\text { Exposure } \\
(\mathrm{mg} / \mathrm{kg} / \mathrm{d})\end{array}$ & $\begin{array}{c}\text { Total } \\
\text { Exposure } \\
(\mathrm{mg} / \mathrm{kg} / \mathrm{d})\end{array}$ & $\begin{array}{l}\text { LOAEL } \\
(\mathrm{mg} / \mathrm{kg} / \mathrm{d})\end{array}$ & Form & HQ \\
\hline Aluminum & & 0.014 & 0 & 1.126 & 0.109 & 0 & 0 & 0 & 0 & 0.0 & $\mathrm{Al} 2(\mathrm{SO} 4) 2$ & \#DIV/0! \\
\hline Arsenic & 16500 & 0.008 & 132 & 1.126 & 0.109 & 0 & 12.77797513 & 0 & 12.77797513 & 12.8 & sodium arsenite & 1.00 \\
\hline Barium & 7000 & 0.061 & 429.8 & 1.126 & 0.109 & 0 & 41.60586146 & 0 & 41.60586146 & 41.7 & $\begin{array}{c}\text { barium } \\
\text { hydroxide }\end{array}$ & 1.00 \\
\hline Cadmium & 1570 & 0.132 & 206.612 & 1.126 & 0.109 & 0 & 20.00062877 & 0 & 20.00062877 & 20.00 & $\begin{array}{l}\text { cadmium } \\
\text { chloride }\end{array}$ & 1.00 \\
\hline Chromium & 233 & 0.221 & 51.5396 & 1.126 & 0.109 & 0 & 4.989179751 & 0 & 4.989179751 & 5.00 & $\begin{array}{c}\mathrm{Cr}+3 \text { as } \\
\mathrm{CrK}(\mathrm{SO} 4) 2\end{array}$ & 1.00 \\
\hline Copper & 860 & 0.740 & 636.572 & 1.126 & 0.109 & 0 & 61.62197869 & 0 & 61.62197869 & 61.7 & copper oxide & 1.00 \\
\hline Lead & 2630 & 0.045 & 117.035 & 1.126 & 0.109 & 0 & 11.3293206 & 0 & 11.3293206 & 11.30 & lead acetate & 1.00 \\
\hline Lithium & & 0.033 & 0 & 1.126 & 0.109 & 0 & 0 & 0 & 0 & & & \#DIV/0I \\
\hline Manganese & & 0.005 & 0 & 1.126 & 0.109 & 0 & 0 & 0 & 0 & 0 & $\mathrm{Mn} 3 \mathrm{O} 4$ & \#DIV/0! \\
\hline Mercury & 0.89 & 0.746 & 0.664385 & 1.126 & 0.109 & 0 & 0.064314356 & 0 & 0.064314356 & 0.064 & $\begin{array}{l}\text { Methyl Mercury } \\
\text { Dicyandiamide }\end{array}$ & 1.00 \\
\hline $\begin{array}{l}\text { Molybdenu } \\
\mathrm{m}\end{array}$ & 36000 & 0.010 & 363.6 & 1.126 & 0.109 & 0 & 35.19751332 & 0 & 35.19751332 & 35.30 & $\begin{array}{l}\text { sodium } \\
\text { molybdate } \\
\text { (MoO4) }\end{array}$ & 1.00 \\
\hline Nickel & 4750 & 0.232 & 1101.05 & 1.126 & 0.109 & 0 & 106.5847691 & 0 & 106.5847691 & 107.00 & nickel sulfate & 1.00 \\
\hline PCB-1254 & & & 0 & 1.126 & 0.109 & 0 & 0 & 0 & 0 & 1.800 & $\mathrm{n} / \mathrm{a}$ & 0.00 \\
\hline PCB-1260 & 3.55 & 5.220 & 18.532065 & 1.126 & 0.109 & 0 & 1.793956559 & 0 & 1.793956559 & 1.800 & $\begin{array}{l}\text { assumed to be } \\
1254\end{array}$ & 1.00 \\
\hline Selenium & 44.5 & 0.231 & 10.2795 & 1.126 & 0.109 & 0 & 0.995084813 & 0 & 0.995084813 & 1.000 & sodium selenite & 1.00 \\
\hline Thallium & & & 0 & 1.126 & 0.109 & 0 & 0 & 0 & 0 & & & \#DIV/O! \\
\hline Uranium & & 0.000 & 0 & 1.126 & 0.109 & 0 & 0 & 0 & 0 & 0.0 & $\begin{array}{l}\text { depleted } \\
\text { mettalic } U\end{array}$ & \#DIV/0! \\
\hline Vanadium & & & 0 & 1.126 & 0.109 & 0 & 0 & 0 & 0 & 0.000 & vanadyl sulfate & \#DIV/0! \\
\hline Zinc & 570 & 2.377 & 1354.947 & 1.126 & 0.109 & 0 & 131.1627202 & 0 & 131.1627202 & 131.0 & zinc sulfate & 1.00 \\
\hline
\end{tabular}




\section{DISTRIBUTION}

1. L. V. Asplund

2. R. R. Bonczek

3. M. Clauberg

4. J. Croswait

5. J. R. Duncan

6-8. R. E. Efroymson

9. K. M. Golden

10. R. K. Holmes

11. J. Jagoe

12-14. D. S. Jones

15-29. S. B. Kerr

30. J. M. Loar

31. D. M. Matteo

32. C. W. McGinn

33. D. B. Miller

34. J. H. Moyer
35. B. D. Nourse

36. D. M. Opresko

37. P. T. Owen

38. S. T. Purucker

39. A. S. Quist

40-42. B. E. Sample

43. D. M. Steinhauff

44-46. G. W. Suter

47. S. S. Talmage

48. M. F. Tardiff

49. C. J. E. Welsh

50. D. C. White

51. M. E. Will

52. ER Document Management Center-RC

53. A. Temeshy, Bechtel National Inc., 151 Lafayette Dr., Oak Ridge, TN 37831-0350

54. M. Leslie, CDM Federal Programs Corporation, 800 Oak Ridge Turnpike, Suite 500, Oak Ridge, TN 37830

55. D. Gonzales, Jacobs Engineering, 125 Broadway, Oak Ridge, TN 37830

56. G. Snyder, Jacobs, Engineering, 100 West 3rd St., Piketon, OH 45611

57. J. Tate, Jacobs, Engineering, 125 Broadway, Oak Ridge, TN 37830

58. D. Wilkes, Jacobs, Engineering, 175 Freedom Blvd., Kevil, KY 42053

59. P. Carter, Science Applications International Corporation, 11197 U.S. Route 23, Suite 200, Waverly, Ohio 45690

60. B. Komaby, Science Applications International Corporation, P.O. Box 2501, 301, Laboratory Rd., Oak Ridge, TN 37831

61. S. Pack, Science Applications International Corporation, P.O. Box 2501, 301, Laboratory Rd., Oak Ridge, TN 37831

62. B. G. Blaylock, SENES, 102 Donner Drive, Oak Ridge, TN 37831

63. K. Hopper, Systematic Management Services, 117 Broadway Ave., Oak Ridge, TN 37830 


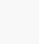


Please do not forward or discard this document.

If this address is not correct for the designated addressee, please return this document to the

ER Central Document Management Center Building K-1002, MS 7243

Martin Marietta Energy Systems, Inc.

P.O. Box 2003

Oak Ridge, TN 37831 